Published in final edited form as:

Mol Aspects Med. 2015 April ; 42: 42-60. doi:10.1016/j.mam.2014.12.004.

\title{
Immunogenetics of Type 1 Diabetes Mellitus
}

\author{
Michael P. Morran ${ }^{1}$, Andrew Vonberg ${ }^{1}$, Anmar Khadra ${ }^{2}$, and Massimo Pietropaolo ${ }^{1,{ }^{*}}$ \\ ${ }^{1}$ Laboratory of Immunogenetics, The Brehm Center for Diabetes Research, Department of \\ Internal Medicine, University of Michigan Medical School, Ann Arbor, Michigan \\ ${ }^{2}$ Department of Physiology, McGill University, Montreal, QC Canada
}

\section{Abstract}

Type 1 diabetes mellitus (T1DM) is an autoimmune disease arising through a complex interaction of both genetic and immunologic factors. Similar to the majority of autoimmune diseases, T1DM usually has a relapsing remitting disease course with autoantibody and $\mathrm{T}$ cellular responses to islet autoantigens, which precede the clinical onset of the disease process. The immunological diagnosis of autoimmune diseases relies primarily on the detection of autoantibodies in the serum of T1DM patients. Although their pathogenic significance remains uncertain, they have the practical advantage of serving as surrogate biomarkers for predicting the clinical onset of T1DM. Type 1 diabetes is a polygenic disease with a small number of genes having large effects, (i.e. HLA) and a large number of genes having small effects. Risk of T1DM progression is conferred by specific HLA DR/DQ alleles [e.g., DRB1*03-DQB1*0201 (DR3) or DRB1*04-DQB1*0302 (DR4)]. In addition, HLA alleles such as DQB $1 * 0602$ are associated with dominant protection from T1DM in multiple populations.

A discordance rate of greater than $50 \%$ between monozygotic twins indicates a potential involvement of environmental factors on disease development. Viral infections may play a role in the chain of events leading to disease, albeit conclusive evidence linking infections with T1DM remains to be firmly established. Two syndromes have been described in which an immunemediated form of diabetes occurs as the result of a single gene defect. These syndromes are termed autoimmune polyglandular syndrome type I (APS-I) or autoimmune polyendocrinopathycandidiasis-ectodermal dystrophy (APECED), and X-linked poyendocrinopathy, immune dysfunction and diarrhea (XPID). These two syndromes are unique models to understand the mechanisms involved in the loss of tolerance to self-antigens in autoimmune diabetes and its associated organ-specific autoimmune disorders. A growing number of animal models of these diseases have greatly helped elucidate the immunologic mechanisms leading to autoimmune diabetes.

\footnotetext{
*To Whom Correspondence May be Addressed: Massimo Pietropaolo, M.D., Division of Diabetes, Endocrinology and Metabolism, Alkek Building for Biomedical Research, R 609, Baylor College of Medicine, 1 Baylor Plaza, Houston, TX 77030, Massimo.Pietropaolo@bcm.edu.

Publisher's Disclaimer: This is a PDF file of an unedited manuscript that has been accepted for publication. As a service to our customers we are providing this early version of the manuscript. The manuscript will undergo copyediting, typesetting, and review of the resulting proof before it is published in its final citable form. Please note that during the production process errors may be discovered which could affect the content, and all legal disclaimers that apply to the journal pertain.
} 


\section{Keywords}

Immunology; Genetics; Pathogenesis; Type 1 diabetes

\section{Introduction}

Type 1 diabetes mellitus is a chronic autoimmune disease in which endogenous insulin production is severely compromised as a result of an immune-mediated injury of pancreatic $\beta$-cells (Eisenbarth, 1986). Genetic analyses of T1DM have linked the HLA complex, mainly class II alleles, to susceptibility to T1DM (Morel et al., 1988; Todd et al., 1987). Viral antigens may also play a role in the generation of beta cell autoimmunity (Lonnrot et al., 2000). The latter observations are supported by the increasing seasonal incidence of T1DM in many Western countries (Orchard et al.1986) and that enteroviruses may be involved in the autoimmune pathogenesis of T1DM (Hyoty, 2002; Lonnrot et al., 2000; Zipris et al., 2007)

Type 1 diabetes was not always considered as the classical organ-specific disease it is now known to be. Insulin-dependent diabetes was known to occasionally occur in the Autoimmune Polyendocrine Syndrome I (APS I), a classic autoimmune syndrome with Tcell and B-cell antibody abnormalities directed at adrenal, parathyroid, gonadal, thyroid and other tissues. However, diabetes mellitus is not a constant, necessary or sufficient feature of APS I (Eisenbarth et al., 2004). This condition is now known to be caused by mutations in the autoimmune regulator gene (AIRE) (Husebye et al., 2010). Bottazzo et al. (1974) reported that sections of human pancreas treated with sera of diabetic patients who also had Addison's disease and myxedema, showed cytoplasmic fluorescence in the islets of Langerhans. This response was termed cytoplasmic islet cell antibodies (ICA) (Bottazzo et al.,1974). Furthermore, the existence of insulin autoantibodies and other autoantibodies against various islet proteins was not uncovered until years later. It was in 1983 that insulin autoantibodies were reported in sera of newly diagnosed patients with T1DM, before any treatment with exogenous insulin (Palmer et al.,1983). In this finding, improvements of the sensitivity of the insulin antibody assay were instrumental for the determination that about one-half of newly diagnosed patients had autoantibodies that bound ${ }^{125}$ I-labeled insulin.

Type 1 diabetes is primarily a T-cell mediated disease. Following the early discoveries on humoral autoimmunity in T1DM, there has been a remarkable expansion in the detection of T1DM-associated autoantibodies as well as in the characterization of the molecular basis of the antigenicity of their target proteins (Atkinson et al., 2001; Pietropaolo et al., 2001). This expansion has led to the uncovering of specific antigenic determinants, the development of biochemically-defined immunoassays and also to coordinated efforts to standardize assays across laboratories (Bonifacio et al., 2010).

\section{Association with other autoimmune diseases}

For reasons not fully understood, patients with an organ-specific autoimmune disease have increased risks of developing autoimmune responses against other organs/tissues (JaberiDouraki et al., 2014; Pietropaolo et al., 2012). Patients with T1DM are at increased risk for 
developing other autoimmune diseases, most commonly autoimmune thyroiditis and celiac disease. Thyroid autoimmunity is particularly common among patients with type $1 \mathrm{~A}$ diabetes, affecting more than one-fourth of individuals, and 2 to 5 percent of patients with type 1 diabetes develop autoimmune hypothyroidism. Transglutaminase autoantibodies are present in approximately 10 percent of patients, and half of these patients have high levels of these autoantibodies and celiac disease on biopsy (Hoffenberg et al., 2004; Jaeger et al., 2001). In addition, certain alleles (e.g., HLA haplotype DR3-DQ2 or DR4-DQ8 PTPN2, CTLA4, RGS1) confer a genetic susceptibility to both T1DM and celiac disease, suggesting a common biological pathway (Liu et al., 2014; Smyth et al., 2008a). Fewer than 1 percent of children with T1DM have autoimmune adrenalitis. In one study, it was reported that 11 of 629 patients (1.7 percent) with type 1 diabetes but none of the 239 normal subjects had antibodies directed against 21-hydroxylase, a common autoantigen in primary adrenal insufficiency (Brewer et al., 1997). A total of 3 out of 8 patients with anti-21-hydroxylase antibodies had adrenal insufficiency.

Type 1 diabetes can be seen with polyglandular autoimmune disease, especially type II, in which adrenal insufficiency, autoimmune thyroid disease, and gonadal insufficiency are the other major components. Rare syndromes associated with T1DM have shed important light on pathogenesis. The immune dysregulation, polyendocrinopathy, enteropathy, X-linked (IPEX) syndrome is associated with neonates developing T1DM. These infants usually die of overwhelming autoimmunity, in particular, severe enteritis. This syndrome is an X-linked recessive immunologic disorder characterized by early onset of Type 1A diabetes mellitus, autoimmune thyroiditis, autoimmune enteropathy, hemolytic anemia, atopic dermatitis including food allergies, and immunodeficiency leading to fatal infections. This syndrome is also known by X-linked autoimmunity-immunodeficiency syndrome (XLAAD). It is important to note that this condition, though extremely rare, can be reversed by bone marrow transplantation. X-linked autoimmunity-immunodeficiency syndrome is caused by a mutation of a gene termed foxp3, a "master-switch" for the development of regulatory $\mathrm{T}$ cells. Studies of the syndrome and the related animal model provide dramatic evidence that regulatory $\mathrm{T}$ cells (formerly termed suppressor $\mathrm{T}$ cells) have a major physiologic role in suppressing autorective T cells. The APS-I syndrome (Autoimmune Polyendocrine Syndrome type 1) is caused by a mutation of the AIRE gene (autoimmune regulator). This gene controls expression of a series of "peripheral" antigens in the thymus, including insulin. It is thought that the gene provides protection from autoimmune disorders, including T1DM, through its influence on the mechanisms involved in central $\mathrm{T}$ cell tolerance (Eisenbarth et al., 2004; Husebye et al., 2010).

\section{Genetic Susceptibility}

In T1DM familial aggregation is indicated by the notion that the overall risk for developing T1DM in North American Caucasian siblings, parents and offspring of individuals with T1DM ranges from 1\% to 15\% (Allen et al.,1986; Dorman et al.,1995; Wagener et al.,1982; Warram et al.,1984; Warram et al.,1994) as compared to less than $1 \%$ for individuals without T1DM relatives and 1.2/1,000 of the general population (LaPorte et al., 1995) (Table 1). 
However, over $80 \%$ of cases of T1DM occur in individuals with no apparent family history of the disease. In the remaining $20 \%$, this disease aggregates in families. The lifelong risk of T1DM is markedly increased in first degree relatives of patients with T1DM, averaging about 6 percent in offspring, 5 percent in siblings, and 50 percent in identical twins (versus 0.4 percent in subjects with no family history) (Kaprio et al.,1992; Redondo et al., 2002). A monozygotic twin of a patient with T1DM has a higher risk of diabetes than a dizygotic twin, and the risk in dizygotic twin siblings is similar to that in non-twin siblings (Table 1). Alleles at each locus on a single chromosome are usually inherited in combination as a unit. This combination is termed haplotype. Since each individual inherits one set of chromosomes from each parent, each individual has two haplotypes. HLA genes are codominant and follow a simple Mendelian form of transmission in families. Therefore, both alleles are expressed at a given HLA locus. There is a $25 \%$ chance that two siblings share the same haplotype and be fully compatible, a 50\% chance that they will share one haplotype, and a $25 \%$ chance that they share no haplotype and thus be HLA incompatible. Siblings with the highest risk HLA DR and DQ alleles (e.g., DR3/DR4 heterozygotes), who inherit both HLA regions identical by descent to their diabetic sibling, may have a risk of developing islet autoimmunity as high as 70 percent and a similar long-term risk of diabetes (Aly et al., 2006) (Table 1).

\subsection{The MHC complex}

The short arm of human chromosome 6 (6p21) accommodates a $~ 3.5$ megabase genetic segment containing a group of immune response genes termed the major histocompatibility complex (MHC) (Figure 1) (Pietropaolo et al., 2000; Wucherpfennig et al., 2001). The main genes localized within the MHC encode human leukocyte antigens, or HLA, two molecular classes of cell surface glycoproteins differing in structure, function, and tissue distribution. While MHC class I molecules are expressed in virtually all nucleated cells, class II molecule expression is restricted to B lymphocytes, dendritic cells, macrophages and activated $\mathrm{T}$ lymphocytes. Both MHC class I and class II molecules are involved in the presentation of antigens to $\mathrm{T}$ cells. Cytotoxic $\mathrm{T}$ cells $\left(\mathrm{CD} 8^{+}\right)$mainly recognize antigen in the context of class I, whereas helper/inducer cells $\left(\mathrm{CD}^{+}\right)$usually recognize antigen in the context of the class II molecules.

Many immunologically mediated diseases, including certain endocrine syndromes are genetically associated with specific HLA molecules and several hypotheses have been suggested to explain HLA-disease associations (Schwartz, 1996). Some HLA-associated diseases have been linked with polymorphisms of the genes encoding the class II molecule. One typical example is T1DM. Other mechanisms beside those discussed above have been implicated as a result of HLA molecule-peptide interactions, but it should be emphasized that more than one mechanism may be operating concurrently to determine susceptibility to a disease process.

The ability of these class II molecules to present antigens is dependent in part upon the amino-acid composition of their alpha and beta chains. Substitutions at one or two critical positions can markedly increase or decrease binding of relevant autoantigens and therefore the susceptibility to type 1 diabetes (Khalil et al.,1990; Rowe et al.,1994). In particular, 
more than 90 percent of patients with type 1 diabetes carry either HLA-DR3, DQB1*0201 (also referred to as DR3-DQ2) or -DR4, DQB1*0302 (also referred to as DR4-DQ8), versus 40 percent of controls with either haplotype; furthermore, about 30 percent of patients have both haplotypes (DR3/4 heterozygotes), which confers the greatest susceptibility (Tisch et al., 1996). The higher risk of this heterozygote compared with the two (DR3/DR3 and DR4/ DR4) homozygotes has been attributed to the two transcomplementing DQ heterodimers, including the a (DQA $1 * 0501)$ and $\mathrm{b}(\mathrm{DQB} 1 * 0302)$ heterodimer, present only in this heterozygote (Erlich et al., 2008). Prospective studies of HLA-typed general population samples and first-degree relatives of T1DM patients have shown that the risk for DR3/DR4 (or DQ2/DQ8) in these relatives is greater than the risk for the same genotype in the general population (Aly et al., 2006), suggesting that additional loci either within or outside the HLA region also contribute to T1DM risk. Among the relatives of T1DM patients, DR3/DR4 siblings have a greater risk than offspring, and DR3/DR4 siblings who share two HLA haplotypes with the proband have an extremely high risk (Aly et al., 2006). Using the DR3/4 genotype (rather than DR3 or DR4) as a predictive marker will identify approximately $20-40 \%$ of future T1DM cases.

The prevalence of HLA-DR2 is decreased in patients with T1DM, and the DQA1*0102/ DQB $1 * 0502 / \mathrm{DRB} 1 * 1601$ haplotype accounts for the most part of disease susceptibility in DR2-associated cases of T1DM (Redondo et al., 2002). Therefore, the originally described effect of the DR2 allele in conferring resistance to diabetes is considered to be neutral rather than protective, whereas the real protective effect is provided by the DQ alleles, generally found in linkage disequilibrium with DR2. The effect of HLA alleles on T1DM susceptibility are summarized in Table 2.

A study of T1DM in Filipinos (Mbunwe et al., 2013) revealed that the common HLA*24:02 allele conferred high diabetes risk, unlike the $A * 24: 07$ allele. The authors concluded that A*24 is an independent predictor of progression to T1DM in antibody-positive relatives of T1DM patients. Clearly, other markers could be implemented into these predictive algorithms but the sensitivity and specificity of $A * 24$ as genetic marker remains to be established.

With regard to the effect of HLA genotypes in other populations, a meta-analysis of HLADQ, DR allele polymorphisms in T1DM revealed that DQA $1 * 0301$, DQA $1 * 0501$, DQB1*0201, DQB1*0302 are high-risk alleles (all $P<0.05$ ) in the Chinese population, whereas the DQA1*0103, DQA1*0201, DQA $1 * 0401$, DQB1*0301, DQB1*0402, DQB1*0501, DQB1*0503, DQB1*0601 and DQB1*0602 alleles are considered protective in this population. DRB $1 * 04$, DRB $1 * 0301$, DRB $1 * 0901$ appear to be susceptible alleles, while DRB1*07, DRB1*08, DRB1*12, DRB1*13, DRB1*14, DRB1*16, DRB1*0406 are considered protective alleles in subjects of Chinese descent. Moreover, the DRB1*0405DQB1*0401 (DR4) and DRB1*1302-DQB1*0604 (DR13) haplotypes are associated with T1DM in Japanese patients (Katahira et al., 2010), whereas the DRB1*0406 alleles confers protection in Japanese (Huang et al.,1995), Sardinian (Cucca et al., 2001) and Spanish (Morales et al.,1991) populations. The DRB1*0405 allele seems to confer strong T1DM susceptibility in the majority of ethnic groups, whereas DRB1*0403 DRB1*0406 appears to confer T1DM protection (She, 2001). 


\subsection{Mechanisms of susceptibility to or protection from T1DM}

The importance of HLA class II molecules in playing a role in the pathogenesis of T1DM is also indicated by studies in a transgenic non-obese diabetic (NOD) mouse model, in which the expression of an I-A $\beta$ chain (the equivalent to the human class II DQB1 locus) transgene carrying Asp 57 instead of Ser 57 protects these mice from developing diabetes (Miyazaki et al.,1990; Slattery et al.,1990). Moreover, expression of Pro 56 instead of the normal His 56 in the I-A $\beta$ chain has the same effect (Lund et al., 1990). Finally, expression of certain I-E (the equivalent of the human HLA-DR locus) transgenes appears to confer resistance to the disease (Lund et al., 1990; Nishimoto et al.,1987). Of note, the treatment of NOD mice with a monoclonal antibody reacting with the murine class II molecule, also prevents the progression to overt diabetes (Boitard et al., 1988). These findings obtained in an animal model of T1DM, certainly support the role of both HLA-DQ and HLA-DR in human T1DM. The interaction between the components of the trimolecular complex $\left(\mathrm{CD} 4^{+}\right.$ T cell receptors, self-peptide, and MHC class II molecules) plays a pivotal role in autoimmune disease pathogenesis. The development of therapies targeting various components of the trimolecular complex for the prevention of type 1 diabetes is actively being pursued (Michels, 2013; Zhang et al., 2014).

The mechanisms by which the class II genes can influence susceptibility to, or protection from, T1DM are still a subject of discussion. Brown et al. (Brown et al.,1993) have characterized the structure of the crystallized HLA class II molecule. One hypothesis is that effective antigen-binding depends on the conformation of the antigen-binding site on the DQ dimer. The two critical residues, DQa 52 and DQ $\beta 57$ are located at opposite ends of the ahelices that form the antigen-binding site of the DQ molecule. Another hypothesis is that a substitution of an amino acid residue at these positions of the DQ molecule leads to conformational changes of the antigen-binding site and, consequently, to a modification of the affinity of the class II molecule for the "diabetogenic" peptide(s). In support of this hypothesis, it is known that in the DR molecule Asp-57 is involved in hydrogen and salt bonding with the antigenic peptide and the Arg-76 position of the a chain, respectively (Lund et al.,1990; Nishimoto et al.,1987; Pietropaolo et al., 2000). Theoretically, modifications in the DRa Arg-76 residue would also alter the antigen-binding site. This is physiologically difficult to observe since the DRa chain is not polymorphic.

The TCR on a given peripheral T-cell is composed of separately encoded $\alpha$ - and $\beta$-chains that are disulfide-linked. These dimers must form a molecular complex with the multi-chain CD3 complex to become functionally active at the cell surface (Michels et al., 2011). Throughout the entire life of an individual, T-cells undergo a constant maturation process occurring primarily in the thymus. During this process, precursor stem cells, initially from the fetal liver and then from bone marrow, enter the thymic anlage, where they are induced to rearrange their germline TCR $a$ and $\beta$ genes (Haars et al., 1986). TCR gene rearrangements are essentially random, and most are nonproductive as a result of out-offrame joints; however, these unsuccessful rearrangements are requisite for the expression of generally a single functional $\alpha / \beta$ TCR at the cell surface. Furthermore, the essentially random nature of these rearrangements among a large number of variable segments ensures an extremely large $\left(10^{10}-10^{15}\right)$ repertoire of distinct antigen specificities present at the 
surface of the unselected thymocyte pool. Once a T-cell expresses a functional TCR at the cell surface, it is subject to either positive or negative selection events in the thymus. Both positive selection and negative selection depend on interactions between the TCR, MHC molecule, and antigenic self-peptide (Figure 2). Positive selection occurs as thymic stromal cells bearing MHC molecules (containing self-peptide fragments) engage TCR molecules on the developing thymocytes and direct their continued maturation into functionally mature $\mathrm{T}$ cells. T-cells with "useless" receptors (i.e., those that cannot bind with sufficient affinity to the MHC molecule) are not driven to mature and expand, and eventually die. Negative selection refers to the poorly understood set of events that specifically eliminates or alternatively "anergizes" potentially autoreactive cells, thereby inducing "tolerance" to self (i.e., self-tolerance). During negative selection, factors such as affinity for self-antigen and antigen load likely influence the final outcome of cell death or clonal anergy. Thus, the peripheral T-cell repertoire of each person (including each individual of two monozygotic twins) is unique (Davey et al.,1994) and is a consequence of both the random generation of TCRs in the initial unselected thymocyte pool as well as of thymic positive and negative selection events.

Autoimmunity is thought to result from an altered balance between two functionally opposite processes, tolerance induction and immune responsiveness. They are dependent on the presence of class I and class II molecules that are able to present tissue specific antigenic peptides. In genetically-susceptible individuals, certain class II molecules may ineffectively present self-peptides, thereby leading to inadequate negative selection of T-cell populations that could later become activated to manifest an autoimmune response. Nepom and Kwok (1998) explained the molecular basis of HLA-DQ associations with T1DM exactly on this basis (Nepom et al.,1998). Paradoxically, some self-peptides that normally negatively select $\mathrm{T}$ cells, are likely to lead to positive selection when the MHC molecule is, for example, the HLA-DQ3.2.

The HLA-DQ3.2 molecule is encoded by DQA1*0301 and DQB1*0302 genes, that are generally present on the most strongly T1DM-associated haplotype also encompassing HLA-DR4. Due to a characteristic structural motif for peptide binding, the HLA-DQ3.2 can be considered an intrinsically "unstable" MHC class II molecule. If in a DQ3.2-positive individual, the T-cells that are negatively selected in the thymus are only those that recognize DQ3.2-peptide complexes in a "stable" high-affinity configuration, and this in turn leads to the release from the thymus of mature T-cells able to establish a potentially autoimmune repertoire in the periphery.

Small structural changes, then, may result in large functional changes in the antigenpresenting capabilities of the class II molecules. One might conceive that the cells from a person who is heterozygous for both $\mathrm{DQ} a$ and $\mathrm{DQ} \beta$ would contain all four chain combinations on their surface. Competition for binding the processed antigen could take place, with effective antigen binding dictated by the conformation of the antigen-binding site on each DQ dimer. Changes at either amino acid DQa-52 or DQ $\beta-57$, located at opposite ends of the alpha helices that form the antigen-binding groove could alter the configuration of the groove. Changes at both positions, would likely inflict a great conformational effect on the molecule's antigen-presentation capability. Such conformational differences may be 
partially responsible for the observed hierarchy in the degree of susceptibility within the group of non-Asp-57 alleles, and for the differences in the degree of protection afforded by each allele within the group of Asp-57 alleles. For example, the protective effect of the Asp-57 DQB 1*0502 allele prevails over that of certain susceptible alleles, such as nonAsp-57 DQB1*0501. Conversely, the susceptible allele non-Asp-57 DQB1*0302 dominates over the protective effect of Asp-57 DQB $1 * 0301$.

Positive and negative selection events can also explain genetic resistance to T1DM. In many populations, the frequency of the DQB $1 * 0602$ allele is rarely found among patients with T1DM (Carcassi et al.,1991; Pugliese et al.,1995). This suggests that this allele may play a protective role in the disease process. During thymic development, an unidentified diabetogenic peptide can preferentially bind to the DQB $1 * 0602$ molecule, and because the relatively higher affinity and/or avidity it has with this than with other DQ molecules, it will form HLA-DQ molecule/antigenic peptide/TCR complexes more efficiently than other molecules. This could lead to negative selection and depletion of potentially self-peptidereactive $\mathrm{T}$ cells. Individuals with a typical $\mathrm{DQB} * 0602$ allele can then delete these potentially dangerous $\mathrm{T}$ cells during thymic maturation and therefore are protected from developing diabetes. At present, carrying a "protective" DQB*0602 allele is considered as a criterion of exclusion for enrolling first-degree relatives of diabetic patients in clinical trials, such as the Diabetes Prevention Trial 1 (DPT-1), which is being carried out in the U.S. This trial has been designed to prevent the progression to the clinical onset of T1DM in individuals considered at high risk to develop the disease (DPT-1 Study Group,1995; Mahon et al., 2009). However, this does not mean that carrying the DQB $1 * 0602$ allele confers protection from developing the disease (Greenbaum et al., 2000b; Pugliese et al.,1999). Our results suggests that prediabetics carrying the HLA haplotype DQA1*0102, DQB $1 * 0602$ have the tendency to be antibody negative for all islet autoantigens (Pietropaolo et al., 2002). Seven percent of prediabetics in this study carried the HLA haplotype DQB $1 * 0602$, which confirms previous observations that the protective effect associated with DQB1*0602 is not absolute (Greenbaum et al., 2000a; Pugliese et al.,1999).

Tolerance to self-molecules is established and maintained through complex mechanisms taking place in both thymus (central tolerance) and peripheral lymphoid organs (peripheral tolerance). Since proteins with tissue-restricted or peripheral expression are traditionally thought to be unavailable for presentation in the thymus, it has been proposed that tolerance to such proteins can only be achieved through mechanisms of peripheral tolerance. Indeed, one attractive hypothesis is that T1DM is essentially due to failure of negative selection of autoreactive $\mathrm{T}$ cells, either in the thymus or in the periphery, or because of a breakdown in tolerance to $\beta$-cell-specific antigens. This hypothesis has received support following thymic transplantation of islet antigens or expression of putative islet cell autoantigens resulting in prevention of diabetes in both NOD mouse and BB rat models (Gerling et al.,1992; Naji et al.,1981).

There is evidence to suggest that molecules with tissue-restricted expression may also be expressed in the thymus (Pugliese et al.,1997). Genes encoding the T1DM-related autoantigens insulin, the neuroendocrine antigen IA-2, glutamic acid decarboxylase (GAD), and the neuroendocrine antigen ICA69 are transcribed in human thymus throughout fetal life 
and childhood (Pugliese et al.,1997). Insulin gene transcription in human thymus was also reported by others and similarly insulin, glucagon, and GAD, ICA69 transcripts were detected in mouse thymus (Mathews et al., 2003). Transcripts of several self-molecules have been detected in the thymus, such as pancreatic and thyroid hormones, neuroendocrine molecules, and other peripheral proteins, raising the concept that self-antigen expression in the thymus may be crucial for the development of self-tolerance.

To investigate ICA69 autoimmunity (Bonner et al., 2012; Pietropaolo et al., 1993), in an elegant recent study two genetically modified mouse lines were generated to modulate thymic ICA69 expression: the heterozygous ICA69del/wt line and the thymic medullary epithelial cell-specific deletion Aire- $\Delta$ ICA69 line (Fan et al., 2014). Suboptimal central negative selection of ICA69-reactive T-cells was observed in both lines. Aire- $\triangle \mathrm{ICA} 69$ mice spontaneously developed coincident autoimmune responses to the pancreas (Figure 3), the salivary glands, the thyroid, and the stomach. These findings established a mechanistic link between compromised thymic ICA69 expression and autoimmunity against multiple ICA69expressing organs, and identified a potential novel mechanism for the development of multiorgan autoimmune diseases (Figure 5).

\subsection{Non-MHC genes}

The genetic susceptibility associated with T1DM has been investigated extensively. Polymorphisms of non-MHC genes are reported to influence the risk of type 1A diabetes including, the insulin, the PTPN22 gene, the cytotoxic T-lymphocyte-associated antigen-4 (CTLA-4), interferon-induced helicase, IL2 receptor (CD25), a lectin-like gene (KIA00350), ERBB3e, and undefined gene at 12q) (Concannon et al., 2009; Cooper et al., 2012; Todd et al., 2007). Genome-wide association studies confirmed the above associations and identified four additional risk loci (BACH2, PRKCQ, CTSH, C1QTNF6) associated with an increased risk of T1DM (Cooper et al., 2008). Furthermore some loci conferring shared risk for celiac disease (RGS1, IL18RAP, CCR5, TAGAP, SH2B3, PTPN22) have been identified (Smyth et al., 2008b). Most loci have small effects, and the variants studied are common.

The Type 1 Diabetes Genetics Consortium (T1DGC), led by Dr. Stephen Rich has captured the majority of the genetic risk for T1DM (Barrett et al., 2009; Howson et al., 2012). Genome-wide association studies of T1DM have identified 55 non-MHC susceptibility loci, which required more detailed mapping in order to identify their candidate genes and causal variants. Using the ImmunoChip, a custom Illumina Infinium genotyping array based upon the robust GWAS results in 12 autoimmune diseases, we performed dense genotyping of regions previously associated with risk of at least one immune-mediated disease in 16,086 T1DM case and control samples and 2,670 families. We identified three novel T1DM loci: 1q32.1, 4q32.3 and 10p11.22/(ITGB1 and NRP1). Using 1000 Genomes Project and ENCODE data, functional impact of the most T1DM-associated variants was predicted. Further, GSEA analysis suggested that T1DM is most similar genetically to multiple sclerosis (MS) and most dissimilar to psoriasis, a result that has biological and possibly clinical implications. In contrast, the genes associated with T2DM appear to be focused on $\beta$-cell function, yet only one T2DM gene (GLIS3) is associated with T1DM (and with neonatal diabetes). 
The insulin gene (INS) region on chromosome $11 \mathrm{p} 15$ became a premier candidate for genetic association with type I diabetes in the early 1980s (Bell et al., 1981; Owerbach et al., 1982; Rotwein et al., 1981). Insulin's central role in metabolism and blood glucose homeostasis and its unique distinction as the only known $\beta$ cell-specific antigen made it a likely frontrunner to account for an inherited susceptibility to diabetes.. Julier et al. (1991) provided evidence for genetic linkage for the insulin gene (IDDM2) with T1DM in a collection of multiplex families from France, USA and North Africa (Julier et al.,1991). Subsequently, the investigations of Bain et al. (2001) have confirmed the evidence of linkage between IDDM2 and T1DM (Bain et al.,1992). Importantly, Bain et al. (1992) demonstrated linkage for $I D D M 2$ independent from the influence of HLA alleles (i.e., $I D D M 1)$ and the parental source of the IDDM2 susceptibility allele.

Detailed sequence analysis of the insulin gene region identified a polymorphic locus which consists of a variable number of tandem repeats, or VNTR, present within the $5^{\prime}$ regulatory region (promoter) adjacent to the coding sequence of the insulin gene. Each repeat element consists of a 14- to 15-bp DNA segment having the consensus nucleotide sequence $\mathrm{A}(\mathrm{C} /$ T)AGGGGT(G/C)C(T/C/G)(G/A/T) (G/T/A)G(G/C/T). The number of repeats within sequenced alleles ranges from 26 to $>200$, with three classes of alleles identified on the basis of overall size: class I, class II and class III. Class I INS VNTR alleles consist of 26-63 repeats, averaging $570 \mathrm{bp}$ in length, and are associated with T1DM susceptibility. Class III alleles consist of 140-200 or more repeats and are considered to be protective from diabetes. In size, class III alleles are the largest variants, averaging over $2.2 \mathrm{~kb}$ in length. Finally, class II alleles (1.2 kb average length) are too rare in the populations studied to draw any conclusion about their association with T1DM susceptibility (Bennett et al.,1995).

A number of studies have suggested that the INS VNTR may have a biological role in the genetic regulation of insulin expression (Kennedy et al.,1995; Lucassen et al.,1994). The proximity of this polymorphism to the INS transcriptional start site ( $<400 \mathrm{bp}$ upstream) makes this an attractive hypothesis.

It has previously been reported that INS mRNA levels in the thymus were correlated with VNTR alleles in opposite fashion to that observed in the pancreas (Bennett et al.,1995). INS transcripts in cis with class III VNTR alleles are transcribed at much higher levels (on average 2-3 fold) than those in cis with class I VNTR alleles (Pugliese et al.,1997). The higher transcription levels detected in thymus could underlie the protective effect associated with class III VNTR alleles, as higher insulin levels in the thymus may more efficiently induce negative selection of insulin-specific T-lymphocytes (or improved selection of regulatory T cells). In contrast, homozygosity for diabetes-associated class I VNTR alleles determines lower insulin levels that may be associated with a less efficient deletion of insulin-specific autoreactive T-cells (or impaired selection of regulatory T cells). Proinsulin appears to be the main product of the insulin gene in the thymus (Pugliese et al.,1997). Direct support for the hypothesis that levels of INS expression in thymus and lymphoid organs could influence T1DM susceptibility was provided by studies in insulin gene knockout mice and transgenic mice (Fan et al., 2009; Nakayama et al., 2005) and more recently in humans (Durinovic-Bello et al., 2014). 
Bottini and coworkers evaluated a functional polymorphism in the lyp gene in two series of T1DM patients, one from Denver and one from Sardinia (Bottini et al., 2004). The Lyp molecule, coded by the PTPN22 locus, is a lymphoid tyrosine phosphatase located on chromosome $1 \mathrm{p} 13$. The relevant diabetes associated polymorphism appears to be a missense mutation that changes an arginine at position 620 to a tryptophan and thereby abrogates the ability of the molecule to bind to the signaling molecule Csk (Bottini et al., 2004; Bottini et al., 2006; Vang et al., 2005). The lyp-Csk complex downregulates T cell receptor signaling and thus loss of this interaction was thought to enhance $\mathrm{T}$ cell receptor signaling, though a study by Bottini and colleagues indicates a gain of function with the missense mutation and inhibition of T-cell receptor signaling. Of note, the minor tryptophan encoded allele is associated with a series of autoimmune disorders including T1DM, rheumatoid arthritis and lupus erythematosus (Vang et al., 2005). A number of studies have confirmed the association of this missense mutation with T1DM including a large study from Great Britain. A gain of function with a missense polymorphism probably also explains why the R620W change is the most widely studied polymorphism within the PTPN22 locus clearly associated with T1DM.

A polymorphism in the CTLA4 gene was shown to be associated with the risk of T1DM in a meta-analysis of 33 studies involving over 5000 patients (Kavvoura et al., 2005). This chromosomal region 2q33 contains the CTLA-4 and CD28 genes, which encode for two molecules that are intimately involved in the regulation of T-cell activation and proliferation. Differential regulation of these molecules could easily affect T-cell function and hence the regulation of immune responses. The CTLA- 4 gene is a strong candidate gene for autoimmune diseases since it encodes for a molecule that functions as a key negative regulator of T-cell activation, and the linked markers encompass a region containing an (AT)n microsatellite located in the $3^{\prime}$ UTR of the CTLA-4 gene. Moreover, the analysis of an A-G transition in the first exon of the CTLA-4 gene, coding for a Thr/Ala substitution in the leader peptide, also showed preferential transmission to affected siblings. Although linkage was not observed in families from Sardinia, U.K., and U.S.A., preferential transmission was observed considering all of the above families together $(n=818)$ (Awata et al., 1998). Further confirmation of association with the IDDM12-CTLA-4 locus came through linkage disequilibrium (association) analysis using a multi-ethnic collection of families with one or more affected children, which included families from Spain, France, China, Korea, and Mexican-Americans. In this study, the transmission disequilibrium test (TDT) revealed a highly significant deviation for transmission of alleles at the (AT)n microsatellite marker in the $3^{\prime}$ untranslated region as well as the A/G polymorphism in the first exon of the CTLA-4 gene (Marron et al., 1997).

\section{Environmental Factors}

Environmental influences are another important factor in the development of type 1 diabetes. Perhaps the best evidence for this influence is the demonstration in multiple populations of a rapid increase in the incidence of type 1A diabetes (Gale, 2002; Vehik et al., 2007). The etiology of the increase is unknown. One hypothesis, termed the hygiene hypothesis, relates improved "sanitation" to increasing immune mediated disorders (Bach, 2002). Twin studies indicate that not all monozygotic twins of probands with type 1 diabetes 
develop diabetes, although the cumulative prevalence increases with long-term follow-up (Kaprio et al.,1992; Redondo et al.,1999; Verge et al.,1995).

Putative environmental factors include viral, microbial, diet-related, anthropometric and psychosocial factors. Ongoing observational cohort studies such as The Environmental Determinants of Diabetes in the Young (TEDDY) study aims to ascertain environmental determinants that may trigger islet autoimmunity and either speed up or slow down the progression to clinical onset in subjects with evidence for persistent islet autoimmunity (Elding Larsson et al., 2014). The TEDDY study should shed light on the role of environmental factors in T1DM development.

Viruses can cause diabetes in animal models either by directly infecting and destroying beta cells or by triggering an autoimmune attack against these cells (Szopa et al.1993). The clearest association of viral infection with the development of spontaneous autoimmune diabetes comes from the observation that biobreeding diabetes-resistant (BB-DR) rats, a diabetes resistant strain of rats related to BB rats but without the severe lymphopenia of BB rats, develop diabetes when infected with the Kilham rat virus (Zipris et al., 2007; Alkanani et al., 2014).

Studies suggest a role for innate immune system activation in this model. In a similar manner, polyinosinic:polycytidylic acid (poly-IC) injections (a mimic of double stranded RNA viruses that induces interferon alpha secretion) can induce diabetes in this model and in a mouse model, where induction of interferon alpha is essential for diabetes development (Devendra et al., 2005).

Recent observations revealed the presence of immunoreactive enteroviral capsid protein, VP1, within beta cells in T1DM, which could be associated with a cellular phenotype consistent with the activation of antiviral response pathways and enhanced sensitivity to apoptosis (Richardson et al., 2013; Richardson et al., 2014). However, the role of viral infections as a cause of beta cell loss in human diabetes remains to be elucidated.

The environmental factors leading to T1DM development are far from being elucidated. However, a number of candidates have been identified, including dietary factors (breast feeding vs. infant formula, highly hydrolysed infant formula vs. conventional infant formula, early/late exposure to gluten, vitamin D deficiency etc.), exposure to certain viral elements or helminths anthropometric and psychosocial factors. (Elding Larsson et al., 2014; Nielsen et al., 2014).

The involvement of the gastrointestinal system in T1DM etiology is suggested by differences in intestinal microbiota composition observed in individuals diagnosed with T1DM or with evidence for islet autoimmunity (Nielsen et at., 2014; Reyes et al., 2013). In addition, proof of concept studies conducted in NOD mice provided evidence to suggest that changes in the composition of intestinal microbiota prevent or reduce T1DM incidence (Wen et al., 2008; Hansen et al., 2014).

It is time to carefully design adequately powered longitudinal studies to determine to what extent changes in the gut microbiota or in the metabolome, affect islet autoimmunity and 
T1DM progression. Can early warning gut microbiota patterns be identified? Do environmental factors trigger islet autoimmunity, i.e. islet autoantibodies in subjects at genetic risk, accelerate the disease progression in islet autoantibody positive subjects, or both? Do epigenetic effects play a role in the etiology of the disease? Is there a trigger or an accelerator of a pre-existing subclinical state of islet autoimmunity that is evident at the time of clinical diagnosis? All of these questions have yet to be answered.

\section{Islet Autoantigens and Humoral Autoimmunity}

An ongoing search has identified several autoantigens within the pancreatic $\beta$-cells that may play important roles in the initiation or progression of autoimmune islet injury. Seminal studies have suggested that using a combination of humoral immunological markers gives a higher predictive value for T1DM progression, and great sensitivity without significant loss of specificity (Verge et al.1996).

As autoimmunity in T1DM progresses from initial activation to a chronic state, there is often a higher number of islet autoantigens reacting with $\mathrm{T}$ cells and autoantibodies. This condition is termed "epitope spreading" (Figure 4). Compelling evidence indicates that islet autoantibody responses against multiple islet autoantigens are associated with progression to overt disease (Verge et al.,1996). A number of additional T1DM-related autoantigens have been identified, which include islet cell autoantigen $69 \mathrm{kDa}$ (ICA69), the islet-specific glucose-6-phosphatase catalytic subunit-related protein (IGRP), chromogranin A (ChgA) the insulin receptor, heat shock proteins, the antigens jun-B,16, CD38 (Pietropaolo and Eisenbarth, 2001), peripherin and glial fibrillary acidic protein (GFAP) etc. (Winer et al., 2003) (Table 3).

During immune system development, lymphocytes that react to self-antigens in the thymus and bone marrow are deleted. However, host molecules, in particular proteins and nucleic acids, are constantly being modified in the course of normal physiological events. A key post-translational modification in autoimmunity appears to be the citrullination of arginine amino acid residues, by the enzymatic deimination of arginine to citrulline (Doyle et al., 2012; Eggleton et al., 2008). This reaction is catalyzed by the enzyme peptidyl arginine deiminase (PAD) (Soderlin et al., 2004). In multiple sclerosis and RA, citrullinated isoforms of myelin basic protein (Moscarello et al., 2007) and fibrin (Masson-Bessiere et al., 2001) have been found in the brain and synovia respectively. It must be pointed out that the detection of anti-citrullinated protein antibodies (ACPA) has proven extremely useful in the early diagnosis and assessment of prognosis in rheumatoid arthritis (RA), and has also led to insights into gene environment effects in autoimmune diseases (Kastbom et al., 2004).

With regard to T1DM, processing of molecules such as insulin within the $\beta$-cell generates peptides that are then taken up by APCs either as whole dead $\beta$-cells or specifically granules of $\beta$-cells for eventual further processing/presentation of islet peptides to self-reactive $\mathrm{T}$ cells (Crawford et al., 2011). Furthermore, Stadinski et al. have shown that chromogranin A (ChgA) is an autoantigen in T1DM (Table 1), and that the peptide WE14 from ChgA stimulates diabetogenic $\mathrm{CD}^{+}{ }^{+} \mathrm{T}$ cell clones (Stadinski et al., 2010). The natural form of the antigen in $\beta$ cell extracts is far more potent than an unmodified synthetic WE14 peptide, 
suggesting that this peptide may be post-translationally modified with a carbonyl group in murine pancreatic islets.

\subsection{Insulin Autoantibodies}

Insulin is a hormone produced by the pancreatic $\beta$-cells, which is not only central to regulating carbohydrate and fat metabolism, but also has a pathological role as T1DM autoantigen. Insulin is the predominant secretory product of pancreatic $\beta$ cells whose autoimmune destruction leads to insulin deficiency and consequent metabolic decompensation of glucose homeostasis (Nakayama et al., 2005). Investigations on the immunologically relevant regions of the insulin molecule, conducted in NOD mice, revealed that the 9-23 amino acid sequence of the insulin B chain (termed B9-23) and the effect of intracellular processing of molecules, such as insulin, within the $\beta$-cell can lead to formation of immunogenic epitopes (Crawford et al., 2011).

A high titer of insulin autoantibodies (IAA) at younger ages is consistent with the concept that these patients develop a more aggressive disease course. In particular, insulin autoantibodies levels greater than $2000 \mathrm{nU} / \mathrm{ml}$ are almost exclusively found in patients who progress to T1DM prior to age 5 years, and less than half of individuals developing T1DM after age 15 years carry detectable levels of IAA. Although these observations emphasize the utility of IAA, particularly in younger populations and justify the need to design trials in such a young group, the success of these intervention strategies depends on the safety and effectiveness of therapeutic regimens.

A study from The Finnish Type 1 Diabetes Prediction and Prevention Study, comprising a large population of 2448 genetically at-risk children (Kimpimaki et al., 2001) demonstrated that IAA are usually the first islet autoantibody to appear in the natural history of T1DM and a powerful identifier of disease progression in children followed from birth (Steck et al., 2011).

\subsection{Glutamic Acid Decarboxylase (GAD) Autoantibodies}

In an earlier seminal report, incubation of rat islets with radioactively labeled $\left[{ }^{35} \mathrm{~S}\right]-$ methionine and subsequent immunoprecipitation of solubilized membranes with serum from newly diagnosed patients with T1DM or controls showed that an antigen with a molecular weight of $64 \mathrm{kDa}$ was precipitated by sera from T1DM patients (Baekkeskov et al.,1989). The antibodies to this $64 \mathrm{kDa}$ antigen were present in about $80 \%$ of new onset patients and in pre-diabetics before the appearance of clinical disease. The nature of the $64 \mathrm{kDa}$ antigen remained unknown until the report by Solimena et al showing autoantibodies to GABAergic neurons and pancreatic $\beta$-cells in an unusual condition termed Stiff Man syndrome (Solimena et al.,1988). Glutamic acid decarboxylase is the enzyme which catalyzes the conversion of glutamic acid to gamma amino butyric acid (GABA), a potent inhibitory neurotransmitter. This led Baekkeskov et al to rapidly identify GAD as the $64 \mathrm{kDa}$ autoantigen in T1DM (Atkinson et al.,1993; Baekkeskov et al.,1990; Karlsen et al.,1991). Other molecular-related forms of GAD, such as the $67 \mathrm{kDa}$ isoform, have subsequently been identified (Hagopian et al.,1993). Autoantibodies against GAD are a predictor of progression to overt diabetes. When coupled with insulin autoantibodies and islet cell 
antibodies (ICA), their ability to predict the likelihood of developing T1DM in asymptomatic first-degree relatives of T1DM patients is quite high.

\subsection{IA-2 (ICA512) Autoantibodies}

The neuroendocrine antigen IA-2 (ICA512) is another major autoantigen in T1DM (Lan et al., 1994). It is an enzymatically inactive member of the tyrosine phosphatase family, involved in regulating insulin secretion. Assessment of the presence of IA-2 autoantibodies contributes to the predictability of the likelihood of developing T1DM. As shown by Verge et al. and others, ICA512 (IA-2) and its homologue IA-2 $\beta$ (phogrin) are both neuroendocrine molecules (Achenbach et al., 2004; Pietropaolo et al., 2002; Verge et al.,1996). The deduced ICA512(IA-2) cDNA sequence reveals a 979-amino acid protein with a single transmembrane region and with significant homology to the receptor-type PTP(RT-PTPase). A PTP homologue, termed phogrin, was subsequently identified. Subcellular fractionation of insulinoma tissue showed that both IA-2 and phogrin had a very similar cellular distribution to that of insulin and carboxypeptidase $\mathrm{H}$, and these two molecules are predominantly localized in the secretory granules of neuroendocrine cells (Mziaut et al., 2006; Wasmeier et al.,1996).

While the main immune reactive region of the IA-2 molecule was thought to reside within its intracellular domain (amino acids 601-979), the inclusion of this region together with other reactive epitope regions of the molecule, (encompassing aa residues 256-979), has permitted the development of highly accurate constructs to assess the presence of antibodies against IA-2 (Kawasaki et al.,1997). However, other research has also suggested that humoral autoimmunity against the intracellular as well as the extracellular domain of the molecule is related to a high risk of faster T1DM development (Morran et al., 2010).

\subsection{Zinc transporter family member 8 (ZnT8) Autoantibodies}

Zinc transporter family member 8 ( $\mathrm{ZnT} 8)$ is a member of the cation diffusion facilitator family, with abundant expression in pancreatic $\beta$-cells, although it is also expressed in extrapancreatic tissues (Chimienti et al., 2004; Wijesekara et al., 2009). In the $\beta$-cell it plays an important physiological role since $\mathrm{Zn}$, which is highly concentrated in $\beta$-cells, is needed for normal insulin storage. $\beta$-cell-specific deletion of ZnT8 in mice results in glucoseintolerance, reduced $\beta$-cell zinc accumulation and anomalous insulin granules, as well as blunted first-phase glucose-stimulated insulin secretion, reduced insulin processing enzyme transcripts and increased proinsulin levels (Wijesekara et al., 2010). Its relevance as an important T1DM autoantigen was first described by Wenzlau and coworkers (Wenzlau et al., 2007), following an evaluation of 68 candidate islet autoantigens compiled from multidimensional analyses of microarray mRNA expression profiling. The assessment of the zinc transporter ZnT8 (Slc30A8 encodes ZnT8), indicated that it was targeted by autoantibodies in $60-80 \%$ of new-onset T1DM compared with $<2 \%$ of healthy controls, $<3 \%$ type 2 diabetic patients and in up to $30 \%$ of patients with other T1DM-associated autoimmune pathologies. Interestingly, ZnT8 antibodies were found in 26\% of T1DM subjects who had not exhibited antibody positivity to other commonly measured autoantigens such as GAD, (IA-2), insulin, or in the assay for cytoplasmic islet cell antibodies (ICA). Further research has revealed polymorphisms in ZnT8 that are relevant to 
its role as a major T1DM autoantigen. There are three polymorphic variants located in the intracellular (C-terminus) domain of the transporter protein, namely Arg 325, Trp325 and Gln 325. Of these variants, $\operatorname{Trp} 325$ (W) and $\operatorname{Arg} 325$ (R) have been shown to be the major autoantigenic polymorphisms in T1DM and use of a construct containing the $\mathrm{W}$ and $\mathrm{R}$ variants (ZnT8WR) (Wenzlau et al., 2008) has proven its efficacy as a screen for T1DM associated humoral autoimmunity. More recently, a chimeric construct containing amino acid residues 609-979 of the intracellular domain of IA-2, linked to peptides containing both ZnT8 W and R polymorphisms has been successfully developed and tested as a broader and more economical screen to detect patients exhibiting humoral autoimmunity against IA-2 and/or ZnT8 (Yu et al., 2010).

Furthermore, Stadinski et al. have shown that chromogranin A (ChgA) is an autoantigen in T1DM (Table 1), and that the peptide WE14 from ChgA stimulates diabetogenic $\mathrm{CD}^{+} \mathrm{T}$ cell clones (Stadinski et al., 2010; Delong et al., 2012). More recently, the same group provided evidence to suggest that WE14 is recognized by T cells from diabetic subjects vs. controls in a dose dependent manner (Gottlieb et al., 2014). The natural form of the antigen in $\beta$ cell extracts is far more potent than an unmodified synthetic WE14 peptide, suggesting that this peptide may be post-translationally modified with a carbonyl group in pancreatic islets.

\subsection{Relevance as predictors of risk for T1DM, role of age and specificity}

Combining both immunologic and metabolic strategies (e.g. oral glucose tolerance test or the first phase $(1+3 \mathrm{~min}$.) insulin response of an intravenous glucose tolerance), the current opinion is that type 1 diabetes progression can be predicted with 80-100\% accuracy within 5 and 10-year follow-up respectively (Xu et al., 2010).

A study on the Diabetes Autoimmunity Study in the Young (DAISY) cohort showed that $89 \%$ of children who progressed to T1DM had two or more islet-related autoantibodies (Steck et al., 2011). Importantly, age of diagnosis of diabetes was strongly correlated with age of appearance of first autoantibody and IAA levels. By life-table analysis, children exhibiting two or more autoantibodies showed a nearly linear progression to diabetes $(P<$ 0.0001 ). Children with persistently positive IAA levels had a higher progression rate to overt T1DM (100\% by 5.6 years) as compared to children with fluctuating IAA levels (63\% by the 10-year follow-up) $(P<0.0001)$. Finally, in children enrolled in the DAISY study followed to the development of diabetes onset, only high IAA titer correlated with rapid progression to T1DM onset $(P<0.0001)$. As a matter of fact, this effect was not evident with respect to the presence of high GAD65 or IA-2/ICA512 autoantibody titer. Therefore, insulin autoantibody levels at the time of diagnosis are inversely related to the age of the patient being highest in those less than 5 years of age and hence, IAA appear to be an early marker of $\beta$-cell destruction. The titer of insulin autoantibodies along with the insulin secretory response judged by the first phase insulin levels at 1 and 3 minutes after an intravenous glucose challenge, has also been successfully employed to construct mathematical models to predict likelihood of clinical diabetes in asymptomatic first-degree relatives of patients (Eisenbarth, 1986). Investigators from the DAISY study reported that 5 children were found to have persistent IAA before 1 year of age, and 4 of them went on to 
develop the clinical onset of T1DM (all before 3.5 years of age). In contrast, children not exhibiting persistent IAA before the age of 1 year, rarely rapidly developed insulin requirement. When analyzing only children followed from birth, who progressed to diabetes, the two major predictors of age of diabetes diagnosis were the age at which autoantibodies first appeared and the mean level of insulin autoantibodies. These observations emphasize the utility of IAA, particularly in younger populations and justify the need to design trials focused on such a young group. However, the success of these strategies depends on the safety and effectiveness of therapeutic regimens. Indeed, this was the strategy in the trial to prevent development of T1DM (DPT-1), which successfully predicted the development of diabetes in first degree relatives of T1DM patients (Skyler et al., 2001).

\section{Role of cellular immunity}

A strong indication that T1DM is an autoimmune disease derived from a comprehensive histological examination of pancreata from T1DM patients who had died shortly after diagnosis (Bottazzo et al.,1985; Conrad et al.,1994; Foulis et al.,1986; Gianani et al., 2010). The majority of the subjects had significant lymphocytic infiltration of their islets concordant with loss of $\beta$-cell mass. With the advent of monoclonal antibodies capable of identifying distinct lymphocyte sub-populations more detailed immunohistochemical examinations of islet infiltrates became possible. One of the earliest of such studies showed a predominance of $\mathrm{CD} 8^{+} \mathrm{T}$-cells in the islets of a deceased 12-year old girl with newly diagnosed T1DM, which, together with the observed up-regulation of MHC class I molecules by islet cells, implicated cytotoxic T-cells (CTLs) in $\beta$-cell destruction (Bottazzo et al.,1985). Additional studies of pancreas from patients with type 1 diabetes have confirmed preponderance of $\mathrm{CD} 8^{+} \mathrm{T}$-cells and the presence of B-lymphocytes related to extent of $\beta$-cell destruction (Conrad et al.,1994). The JDRF nPOD (Network for Pancreatic Organ Donors with Diabetes) program now allows viewing of pancreatic histology of cadaveric donors directly online (http://www.jdrfnpod.org/) (Pugliese et al., 2014).

In T1DM autoimmune responses are influenced by a balance between pathogenic and regulatory T lymphocytes (Bluestone et al., 2005). While the role of autoimmunity in the pathogenesis of type 1 diabetes and the frequent development of autoantibodies are not in question, there is compelling evidence for a major role of cellular immunity in disease pathogenesis. Antigen peptides are presented by major histocompatibility complexes (MHC) on antigen presenting cells that activate and mobilize effector $\mathrm{CD} 4^{+}$and $\mathrm{CD} 8^{+} \mathrm{T}$ cell populations that are required for disease induction (Haskins et al.,1988; Mallone et al., 2007). The formation of the immunological synapse containing T cell receptor, MHC, and cognate auto-antigen can be performed by a number of different antigen presenting cells. These can include dendritic cells, macrophages, and B cells.

Naturally-processed epitopes of islet cell autoantigens represent the targets of effector and regulatory $\mathrm{T}$ cells in controlling pancreatic beta cell-specific autoimmune responses ( $\mathrm{Di}$ Lorenzo et al., 2007). In particular, naturally processed HLA class II allele-specific epitopes recognized by $\mathrm{CD}^{+} \mathrm{T}$ cells, corresponding to the intracellular domain of IA-2, were identified after native IA-2 antigen was delivered to EBV-transformed B cells and peptides eluted and analyzed by mass spectrometry (Allen et al., 2009; Peakman et al., 2000). 
Furthermore, dendritic cell subsets can process and present soluble IA-2 to $\mathrm{CD} 4^{+} \mathrm{T}$-cells after short-term culture, but only plasmacytoid dendritic cells enhance (by as much as 100 percent) autoantigen presentation in the presence of IA-2 autoantibody patient serum (Allen et al., 2009). The plasmacytoid subset of dendritic cells is overrepresented in the blood close to T1DM onset and shows a distinctive ability to capture islet autoantigenic immune complexes and enhance autoantigen-driven $\mathrm{CD} 4{ }^{+} \mathrm{T}$-cell activation. This suggests a synergistic proinflammatory role for plasmacytoid dendritic cells and IA-2 autoantibodies in T1DM. Taken together, these observations may lead to identification of novel naturallyprocessed epitopes recognized by $\mathrm{CD} 4^{+} \mathrm{T}$ cells, which may represent potential therapeutic agents, either in native form or as antagonistic altered peptide ligands, for the treatment of T1DM.

Traditionally, one of the main sources of tolerance induction is the $\mathrm{CD} 4{ }^{+} \mathrm{CD} 25^{+} \mathrm{FoxP} 3^{+}$ regulatory $\mathrm{T}$ cell population, which secretes IL-10 as its hallmark cytokine and induces anergy and apoptosis in activated effector $\mathrm{CD} 4^{+}$and $\mathrm{CD} 8^{+} \mathrm{T}$ cells. Alterations in number and function of this regulatory cell population may contribute to the generation of an autoimmune state in Type 1 diabetes (Bluestone et al., 2006). Results from a clinical trial of a humanized anti-CD3 monoclonal antibody in new onset T1DM suggest that this treatment improves metabolic control beyond one year after treatment (Herold et al., 2002; Tang et al., 2013). This monoclonal antibody, termed hOKT3 $\gamma 1$ (Ala-Ala) contains the binding region of OKT3 in which the $\mathrm{C}_{\mathrm{H}} 2$ region has been modified by site-directed mutagenesis to alter FcRbinding activity The outcome was the elimination $\mathrm{T}$ cell activation properties and to induce $\mathrm{T}$ cells with regulatory capabilities. The rationale for the clinical trial using the "humanized" hOKT3 $\gamma 1$ (Ala-Ala) monoclonal antibody is based on the observation that in NOD mice antiCD3 mAb treatment reverses hyperglycemia in newly diagnosed NOD mice as a result of the induction of regulatory T cells (Chatenoud et al., 1994).

The CD40-CD40 ligand (CD40L) interaction is one of the most important receptor-ligand interactions that occurs during a $\mathrm{T}$ dependent immune response. CD40L is expressed on a range of cell types including activated $\mathrm{T}$ and $\mathrm{B}$ cells, dendritic cells granulocytes, macrophages and platelets. One of the most widely studied reagents used to block CD28/ CD80/86 interactions is the Ig fusion protein construct CTLA4-Ig (abatacept). CTLA4 (CD152) is expressed on T cells and also binds to CD80 and CD86 with high affinity. A very promising clinical trial indicated that costimulation modulation with abatacept slowed decline in beta cell function and improved HbAlc in newly diagnosed T1DM patients. This beneficial effect was sustained for at least one year after cessation of abatacept infusions or three years from T1DM diagnosis (Orban et al., 2014). Thus, abatacept appears to hold great promise as an effective therapy to prevent T1DM in subject at risk of progressing to the clinical onset of the disease.

NKT cells may also play a role in the pathogenesis of T1DM in both humans (Wilson et al., 2000) and NOD mice (Sharif et al., 2002). NKT cells could have a general function of suppressing autoimmunity. For instance, reduced frequencies of these cells were reported in patients with T1DM (Wilson et al.,1998), although others (Lee et al., 2002) did not confirm these results. NKT cell importance in NOD mice has been demonstrated by genetic disruption of CD1, which results in the absence of CD1-restricted invariant NKT cells (Shi 
et al., 2001). In these mice, diabetes develops at an earlier age as well as an increased number of memory autoreactive and activated $\mathrm{T}$ cells. In addition, administration of the NKT agonist a galactosyl ceramide (aGalCer) dramatically reduces the frequency of diabetes in NOD mice aGalCer also prevents autoimmune recurrence in spontaneously diabetic mice transplanted with syngeneic islet grafts. The proposed mechanism of action consists of a) NKT cell induction of tolerogenic dendritic cells in draining pancreatic lymph nodes; b) induction of regulatory cytokines; (Sharif et al., 2002) and b) NKT cell induction of tolerogenic dendritic cells in draining pancreatic lymph nodes (Naumov et al., 2001).

The importance of B cells in the pathogenicity of T1DM was initially studied in the nonobese diabetic (NOD) mouse model. Initial generation of a transgenic NOD mouse containing an IgM null gene leading to a lack of B cells clearly showed that these mice were highly resistant to T1DM onset as compared to controls (Serreze et al., 1996). However, upon successful reconstitution of the B cell compartment, IgM null NOD mice went on to develop robust diabetes (Vong et al., 2011). In another study using anti-IgM depleting antibodies to eliminate the B cell repertoire, NOD mice receiving treatment with anti-IgM were protected from T1DM (Noorchashm et al.,1997). Furthermore, using B cell receptor transgenics, it was shown that mice having even slightly increased (1-3\%) B cell receptor specificity for insulin significantly increased insulitis and T1DM progression, whereas mice with decreased B cell receptor specificity for insulin were protected from T1DM (Hulbert et al., 2001). B cells typically play important roles in disease progression: autoantibody production and antigen presentation. An early study to determine whether B cells played a role as presenters or antibody secretors was used in IgM null NOD mice. B cell deficient NOD mice receiving transfers of isolated immunoglobulins taken from diabetic NOD donors did not lead to disease onset, but reconstitution of the B cell repertoire from NOD donors led to increased $\mathrm{T}$ cell activation against beta cell autoantigens (Serreze et al.,1998). The generation of a NOD transgenic mouse that expressed only membrane-bound IgM capable of presenting antigen was able to induce T1DM in an IgM null NOD mouse as compared to NOD control mice (Wong et al., 2004). Further work using transgenic NOD mice with B cell receptor specificity to the irrelevant hen egg lysozyme (HEL) antigen led to decreased disease progression similar to what was seen in the IgM null NOD mice, showing the importance of B cell specific presentation of diabetes autoantigens over other antigen presenting cells in disease pathogenesis (Silveira et al., 2002). Moreover, one such B cell population that is thought to play an important role in diabetes progression are marginal zone (MZ) B cells, which act as potent antigen presenters to naïve CD4+ T cells (Falcone et al.,1998).

More recently, it has been shown that antigen-matured Bregs may maintain tolerance to islet autoantigens by selectively suppressing autoreactive T-cell responses (Kleffel et al., 2014). In the context of T1DM pathogenesis, the inflammatory microenvironment may render this B cell subset functionally impaired or apoptotic.

Other observations suggest that a unique immune phenotype exists in the B cell compartment of healthy individuals who carry the PTPN22 1858T variant (Habib et al., 2012). It has been hypothesized that Lyp620W-mediated effects may contribute to breakdown of peripheral tolerance and the entry of autoreactive B cells into the naive B cell 
compartment. Thus, altered $\mathrm{B}$ cell homeostasis in subjects who express this variant appears to be characterized by an increase in transitional and $\mathrm{D} 19^{+} \mathrm{CD} 27^{-} \mathrm{IgD}^{+} \mathrm{IgM}^{-} \mathrm{B}_{\mathrm{ND}} \mathrm{B}$ cells, as well as blunted BCR signaling in naive mature B cells. The identification of the pathways that are impacted by Lyp620W may provide clues for understanding the predisposition to autoimmune diseases associated with this variant, as well as the response to B cell-directed therapies.

\section{Concluding Remarks}

Type 1 diabetes results from autoimmune destruction/dysfunction of pancreatic $\beta$ cells. In physiologic conditions there is balance between pathogenic $\mathrm{T}$ cells that mediate disease such as $\mathrm{T}$ cells with marked conservation of their TCRs (e.g. insulin), and regulatory cells that control autoimmunity. In T1DM and other autoimmune disorders, there is an altered balance between pathogenic and regulatory $\mathrm{T}$ cells. Development of therapies targeting specific $\mathrm{T}$ and $\mathrm{B}$ lymphocytes is underway in animal models of autoimmune diabetes and eventually may be examined in humans.

In T1DM, the use of genome-wide scans has identified over 40 putative loci of statistical significance but for now only linkage to HLA loci seems incontestable. Albeit much excitement has recently been generated by the results of genome-wide scans, for many polygenic disorders including T1DM, careful and rigorous replication as well as association studies in many populations must be conducted before any attempts are made to identify potentially elusive sequence variations that are thought to influence genetic susceptibility.

Post-translational modifications (PTM) enhance immunostimolatory properties (generation of neoantigens, neoepitopes) in autoimmune diseases such as RA and SLE. It is quite possible that in T1DM altered islet neoantigens may play a critical role in enhancing $\mathrm{T}$ cell immunogenicity as the attendant hyperglycemic and pro-oxidative metabolic milieu includes abnormal glycosylations and oxidative damage to proteins within pancreatic beta cells (Pietropaolo et al., 2012; Roep et al., 2014; van Lummel et al., 2014).

\section{Acknowledgments}

This work was supported by the National Institutes of Health (Grant Number: R01 DK53456, R01 DK56200) to MP, the Michigan Institute for Clinical \& Health Research (MICHR), and the Clinical and Translational Science Award (CTSA) program: UL1RR024986 (MP), and by the National Institute of Diabetes and Digestive and Kidney Diseases (Grant Number P30DK020572: MDRC, P30DK092926: MCDTR). We greatly acknowledge the McNair Medical Institute for its support.

\section{References}

Achenbach P, Warncke K, Reiter J, Naserke HE, Williams AJ, Bingley PJ, Bonifacio E, Ziegler AG. Stratification of type 1 diabetes risk on the basis of islet autoantibody characteristics. Diabetes. 2004; 53(2):384-392. [PubMed: 14747289]

Allen C, Palta M, D'Alessio DJ. Incidence and differences in urban-rural seasonal variation of type 1 (insulin-dependent) diabetes in Wisconsin. Diabetologia. 1986; 29:629-633. [PubMed: 3792695]

Allen JS, Pang K, Skowera A, Ellis R, Rackham C, Lozanoska-Ochser B, Tree T, Leslie RD, Tremble JM, Dayan CM, Peakman M. Plasmacytoid dendritic cells are proportionally expanded at diagnosis of type 1 diabetes and enhance islet autoantigen presentation to T-cells through immune complex capture. Diabetes. 2009; 58(1):138-145. [PubMed: 18835928] 
Alkanani AK, Hara N, Gianani R, Zipris D. Kilham rat virus-induced type 1 diabetes involves beta cell infection and intra-islet JAK-STAT activation prior to insulitis. Virology. 2014; 468-470C:19-27.

Aly TA, Ide A, Jahromi MM, Barker JM, Fernando MS, Babu SR, Yu L, Miao D, Erlich HA, Fain PR, Barriga KJ, Norris JM, Rewers MJ, Eisenbarth GS. Extreme genetic risk for type 1A diabetes. Proc Natl Acad Sci USA. 2006; 103(38):14074-14079. [PubMed: 16966600]

Atkinson MA, Eisenbarth GS. Type 1 diabetes: new perspectives on disease pathogenesis and treatment. Lancet. 2001; 358(9277):221-229. [PubMed: 11476858]

Atkinson MA, Kaufman DL, Newman D, Tobin AJ, Maclaren NK. Islet cell cytoplasmic autoantibody reactivity to glutamate decarboxylase in insulin-dependent diabetes. J Clin Invest. 1993; 91:350356. [PubMed: 8423231]

Awata T, Kurihara S, Iitaka M, Takei S, Inoue I, Ishii C, Negishi K, Izumida T, Yoshida Y, Hagura R, Kuzuya N, Kanazawa Y, Katayama S. Association of CTLA-4 gene A-G polymorphism (IDDM12 locus) with acute-onset and insulin-depleted IDDM as well as autoimmune thyroid disease (Graves' disease and Hashimoto's thyroiditis) in the Japanese population. Diabetes. 1998; 47(1):128-129. [PubMed: 9421386]

Bach JF. The effect of infections on susceptibility to autoimmune and allergic diseases. N Engl J Med. 2002; 347(12):911-920. [PubMed: 12239261]

Baekkeskov S, Aanstoot H, Christgau S, Reetz A, Solimena MS, Cascalho M, Folli F, Richter-Olsen $\mathrm{H}$, DeCamilli P. Identification of the $64 \mathrm{~K}$ autoantigen in insulin dependent diabetes as the GABAsynthesizing enzyme glutamic acid decarboxylase. Nature. 1990; 347:151-156. [PubMed: 1697648]

Baekkeskov S, Warnock G, Christie M, Rajotte RV, Larsen PM, Fey S. Revelation of specificity of 64K autoantibodies in IDDM serums by high-resolution 2-D gel electrophoresis: unambiguous identification of 64K target antigen. Diabetes. 1989; 38:1133-1141. [PubMed: 2670643]

Bain SC, Prins JB, Hearne CM, Rodrigues NR, Rowe BR, Pritchard LE, Ritchie RJ, Hall JRS, Undlien DE, Ronningen KS, Dunger DB, Barnett AH, Todd JA. Insulin gene region-encoded susceptibility to type I diabetes is not restricted to HLA-DR4-positive individuals. Nat Genet. 1992; 2:212-215. [PubMed: 1345171]

Barrett JC, Clayton DG, Concannon P, Akolkar B, Cooper JD, Erlich HA, Julier C, Morahan G, Nerup J, Nierras C, Plagnol V, Pociot F, Schuilenburg H, Smyth DJ, Stevens H, Todd JA, Walker NM, Rich SS. Genome-wide association study and meta-analysis find that over 40 loci affect risk of type 1 diabetes. Nat Genet. 2009; 41(6):703-707. [PubMed: 19430480]

Bell GI, Karam JH, Rutter WJ. Polymorphic DNA region adjacent to the $5^{\prime}$ end of the human insulin gene. Proc Natl Acad Sci USA. 1981; 78:5759-5763. [PubMed: 6272317]

Bennett ST, Lucassen AM, Gough SCL, Powell EE, Undlien DE, Pritchard LE, Merriman ME, Kawaguchi Y, Dronsfield MJ, Pociot F, Nerup J, Bouzekri N, Cambon-Thomsen A, Rønningen KS, Barnett AH, Bain SC, Todd JA. Susceptibility to human type I diabetes at IDDM2 is determined by tandem repeat variation at the insulin gene minisatellite locus. Nat Genet. 1995; 9:284-292. [PubMed: 7773291]

Bluestone JA, Boehmer H. Regulatory T cells. Semin Immunol. 2006; 18(2):77.

Bluestone JA, Tang Q. How do CD4+CD25+ regulatory T cells control autoimmunity? Curr. Opin Immunol. 2005; 17(6):638-642.

Boitard C, Bendelac A, Richard MF, Carnaud C, Bach JF. Prevention of diabetes in nonobese diabetic mice by anti-I-A monoclonal antibodies: transfer of protection by splenic T cells. Proc Natl Acad Sci USA. 1988; 85:9719-9723. [PubMed: 3264405]

Bonifacio E, Yu L, Williams AK, Eisenbarth GS, Bingley PJ, Marcovina SM, Adler K, Ziegler AG, Mueller PW, Schatz DA, Krischer JP, Steffes MW, Akolkar B. Harmonization of glutamic acid decarboxylase and islet antigen-2 autoantibody assays for national institute of diabetes and digestive and kidney diseases consortia. J Clin Endocrinol Metab. 2010; 95(7):3360-3367. [PubMed: 20444913]

Bonner SM, Pietropaolo SL, Fan Y, Chang Y, Sethupathy P, Morran MP, Beems M, Giannoukakis N, Trucco G, Palumbo MO, Solimena M, Pugliese A, Polychronakos C, Trucco M, Pietropaolo M. Sequence variation in promoter of Ical gene, which encodes protein implicated in type 1 diabetes, 
causes transcription factor autoimmune regulator (AIRE) to increase its binding and down-regulate expression. J Biol Chem. 2012; 287(21):17882-17893. [PubMed: 22447927]

Bottazzo GF, Dean BM, McNally JM, Mackay EH, Swift PGF, Gamble DR. In situ characterization of autoimmune phenomena and expression of HLA molecules in the pancreas in diabetic insulitis. $\mathrm{N}$ Engl J Med. 1985; 313:353-360. [PubMed: 3159965]

Bottazzo GF, Florin-Christensen A, Doniach D. Islet-cell antibodies in diabetes mellitus with autoimmune polyendocrine deficiencies. Lancet. 1974; 2:1279-1282. [PubMed: 4139522]

Bottini N, Musumeci L, Alonso A, Rahmouni S, Nika K, Rostamkhani M, MacMurray J, Meloni GF, Lucarelli P, Pellecchia M, Eisenbarth GS, Comings D, Mustelin T. A functional variant of lymphoid tyrosine phosphatase is associated with type I diabetes. Nat Genet. 2004; 36(4):337-338. [PubMed: 15004560]

Bottini N, Vang T, Cucca F, Mustelin T. Role of PTPN22 in type 1 diabetes and other autoimmune diseases. Semin Immunol. 2006; 18(4):207-213. [PubMed: 16697661]

Brewer KW, Parziale VS, Eisenbarth GS. Screening patients with insulin-dependent diabetes mellitus for adrenal insufficiency. N Engl J Med. 1997; 337:202. [PubMed: 9221352]

Brown JH, Jardetzky TS, Gorga JC, et al. Three-dimensional structure of the human class II histocompatibility antigen HLA-DR1. Nature. 1993; 364:33-39. [PubMed: 8316295]

Carcassi C, Trucco G, Trucco M, Contu L. A new HLA-DR2 extended haplotype is involved in IDDM susceptibility. Hum Immunol. 1991; 31:159-164. [PubMed: 1890017]

Chatenoud L, Thervet E, Primo J, Bach JF. Anti-CD3 antibody induces long-term remission of overt autoimmunity in nonobese diabetic mice. Proc Natl Acad Sci USA. 1994; 91(1):123-127. [PubMed: 8278351]

Chimienti F, Devergnas S, Favier A, Seve M. Identification and cloning of a beta-cell-specific zinc transporter, ZnT-8, localized into insulin secretory granules. Diabetes. 2004; 53(9):2330-2337. [PubMed: 15331542]

Concannon P, Rich SS, Nepom GT. Genetics of type 1A diabetes. N Engl J Med. 2009; 360(16):16461654. [PubMed: 19369670]

Conrad B, Weidmann E, Trucco G, Rudert WA, Ricordi C, Rodriquez-Rilo H, Behboo R, Finegold D, Trucco M. Evidence for superantigen involvment in insulin-dependent diabetes mellitus etiology. Nature. 1994; 371:351-355. [PubMed: 8090207]

Cooper JD, Howson JM, Smyth D, Walker NM, Stevens H, Yang JH, She JX, Eisenbarth GS, Rewers M, Todd JA, Akolkar B, Concannon P, Erlich HA, Julier C, Morahan G, Nerup J, Nierras C, Pociot F, Rich SS. Confirmation of novel type 1 diabetes risk loci in families. Diabetologia. 2012; 55(4):996-1000. [PubMed: 22278338]

Cooper JD, Smyth DJ, Smiles AM, Plagnol V, Walker NM, Allen JE, Downes K, Barrett JC, Healy BC, Mychaleckyj JC, Warram JH, Todd JA. Meta-analysis of genome-wide association study data identifies additional type 1 diabetes risk loci. Nat Genet. 2008; 40(12):1399-1401. [PubMed: 18978792]

Crawford F, Stadinski B, Jin N, Michels A, Nakayama M, Pratt P, Marrack P, Eisenbarth G, Kappler JW. Specificity and detection of insulin-reactive CD4+ T cells in type 1 diabetes in the nonobese diabetic (NOD) mouse. Proc Natl Acad Sci US A. 2011; 108(40):16729-16734.

Cucca F, Dudbridge F, Loddo M, Mulargia AP, Lampis R, Angius E, De Virgiliis S, Koeleman BP, Bain SC, Barnett AH, Gilchrist F, Cordell H, Welsh K, Todd JA. The HLA-DPB1--associated component of the IDDM1 and its relationship to the major loci HLA-DQB1, -DQA1, and -DRB1. Diabetes. 2001; 50(5):1200-5. [PubMed: 11334427]

Delong T, Baker RL, He J, Barbour G, Bradley B, Haskins K. Diabetogenic T-cell clones recognize an altered peptide of chromogranin A. Diabetes. 2012; 61(12):3239-46. [PubMed: 22912420]

Davey MP, Meyer MM, Bakke AC. T cell receptor Vb gene expression in monozygotic twins: discordance in CD8 subset and in disease states. J Immunol. 1994; 152:315-321. [PubMed: 7902857]

Devendra D, Jasinski J, Melanitou E, Nakayama M, Li M, Hensley B, Paronen J, Moriyama H, Miao D, Eisenbarth GS, Liu E. Interferon-alpha as a mediator of polyinosinic:polycytidylic acid-induced type 1 diabetes. Diabetes. 2005; 54(9):2549-2556. [PubMed: 16123342] 
Di Lorenzo TP, Peakman M, Roep BO. Translational mini-review series on type 1 diabetes: Systematic analysis of T cell epitopes in autoimmune diabetes. Clin Exp Immunol. 2007; 148(1): 1-16. [PubMed: 17349009]

Dorman, JS.; McCarthy, BJ.; O'Leary, AL.; Koehler, AN. Diabetes in America. National Institute of Diabetes and Digestive and Kidney Diseases; 1995. Risk factors for insulin-dependent diabetes; $\mathrm{p}$. 165-177.

Doyle HA, Mamula MJ. Autoantigenesis: the evolution of protein modifications in autoimmune disease. Curr Opin Immunol. 2012; 24(1):112-118. [PubMed: 22209691]

DPT-1 Study Group . The Diabetes Prevention Trial-type 1diabetes (DPT-1): implementation of screening and staging of relatives. Transpl Proc. 1995; 27(6):3377.

Durinovic-Bello I, Gersuk VH, Ni C, Wu R, Thorpe J, Jospe N, Sanda S, Greenbaum CJ, Nepom GT. Avidity-dependent programming of autoreactive T cells in T1D. PLoS One. 2014; 9(5):e98074. [PubMed: 24844227]

Eggleton P, Haigh R, Winyard PG. Consequence of neo-antigenicity of the 'altered self'. Rheumatol. 2008; 47(5):567-571.

Eisenbarth GS. Type I diabetes mellitus: a chronic autoimmune disease. N Engl J Med. 1986; 314:1360-1368. [PubMed: 3517648]

Eisenbarth GS, Gottlieb PA. Autoimmune polyendocrine syndromes. N Engl J Med. 2004; 350(20): 2068-2079. [PubMed: 15141045]

Elding Larsson H, Vehik K, Gesualdo P, Akolkar B, Hagopian W, Krischer J, Lernmark Å, Rewers M, Simell O, She JX, Ziegler A, Haller MJ. TEDDY Study Group. Children followed in the TEDDY study are diagnosed with type 1 diabetes at an early stage of disease. Pediatr Diabetes. 2014; 15(2):118-26. [PubMed: 24034790]

Erlich H, Valdes AM, Noble J, Carlson JA, Varney M, Concannon P, Mychaleckyj JC, Todd JA, Bonella P, Fear AL, Lavant E, Louey A, Moonsamy P. HLA DR-DQ Haplotypes and Genotypes and Type 1 Diabetes Risk: Analysis of the Type 1 Diabetes Genetics Consortium Families. Diabetes. 2008; 57(4):1084-92. [PubMed: 18252895]

Falcone M, Lee J, Patstone G, Yeung B, Sarvetnick N. B lymphocytes are crucial antigen-presenting cells in the pathogenic autoimmune response to GAD65 antigen in nonobese diabetic mice. $\mathrm{J}$ Immunol. 1998; 161(3):1163-1168. [PubMed: 9686575]

Fan Y, Gualtierotti G, Tajima A, Grupillo M, Coppola A, He J, Bertera S, Owens G, Pietropaolo M, Rudert WA, Trucco M. Compromised central tolerance of ICA69 induces multiple organ autoimmunity. J Autoimmun. 2014; 53:10-25. [PubMed: 25088457]

Fan Y, Rudert WA, Grupillo M, He J, Sisino G, Trucco M. Thymus-specific deletion of insulin induces autoimmune diabetes. EMBO J. 2009; 28(18):2812-2824. [PubMed: 19680229]

Foulis AK, Liddle CN, Farquharson MA, Richmond JA, Weir RS. The histopathology of the pancreas in type (insulin-dependent) diabetes mellitus: a 25-year review of deaths in patients under 20 years of age in the United Kingdom. Diabetologia. 1986; 29:267-274. [PubMed: 3522324]

Gale EA. The rise of childhood type 1 diabetes in the 20th century. Diabetes. 2002; 51(12):3353-3361. [PubMed: 12453886]

Gerling IC, Serreze DV, Christianson SW, Leiter EH. Intrathymic islet cell transplantation reduces bCell autoimmunity and prevents diabetes in NOD/Lt Mice. Diabetes. 1992; 41:1672-1676. [PubMed: 1446808]

Gianani R, Campbell-Thompson M, Sarkar SA, Wasserfall C, Pugliese A, Solis JM, Kent SC, Hering BJ, West E, Steck A, Bonner-Weir S, Atkinson MA, Coppieters K, von Herrath M, Eisenbarth GS. Dimorphic histopathology of long-standing childhood-onset diabetes. Diabetologia. 2010; 53(4): 690-8. [PubMed: 20062967]

Gottlieb PA, Delong T, Baker RL, Fitzgerald-Miller L, Wagner R, Cook G, Rewers MR, Michels A, Haskins K. Chromogranin A is a T cell antigen in human type 1 diabetes. J Autoimmun. 2014; 50:38-41. [PubMed: 24239002]

Greenbaum CJ, Schatz DA, Cuthbertson D, Zeidler A, Eisenbarth GS, Krischer JP. Islet cell antibodypositive relatives with human leukocyte antigen DQA $1 * 0102$, DQB $1 * 0602$ : identification by the Diabetes Prevention Trial-type 1. J Clin Endocrinol Metab. 2000; 85(3):1255-1260. [PubMed: 10720072] 
Greenbaum CJ, Schatz DA, Cuthbertson D, Zeidler A, Eisenbarth GS, Krischer JP. for the Diabetes Prevention Trial - Type 1 Study Group. Islet cell antibody-positive relatives with human leukocyte antigen DQA1*0102, DQB1*0602: identification by the Diabetes Prevention Trial-type 1. J Clin Endocrinol Metab. 2000b; 85(3):1255-1260. [PubMed: 10720072]

Haars R, Kronenberg H, Gallaten WM, Weissman IL, Owen FL, Hood L. Rearrangement and expression of T cell antigen receptor and g-genes during thymic development. J Exp Med. 1986; 164(1):1-24. [PubMed: 3487610]

Habib T, Funk A, Rieck M, Brahmandam A, Dai X, Panigrahi AK, Luning Prak ET, Meyer-Bahlburg A, Sanda S, Greenbaum C, Rawlings DJ, Buckner JH. Altered B cell homeostasis is associated with type I diabetes and carriers of the PTPN22 allelic variant. J Immunol. 2012; 188(1):487-96. [PubMed: 22105996]

Hagopian WA, Michelsen B, Karlsen AE, Larsen F, Moody A, Grubin CE, Rowe R, Petersen J, McEvoy R, Lernmark A. Autoantibodies in IDDM primarily recognize the 65,000-Mr rather than the 67,000-Mr isoform of glutamic acid decarboxylase. Diabetes. 1993; 42:631-636. [PubMed: 8454115]

Hansen CH, Krych L, Buschard K, Metzdorff SB, Nellemann C, Hansen LH, Nielsen DS, Frøkiær H, Skov S, Hansen AK. A maternal gluten-free diet reduces inflammation and diabetes incidence in the offspring of NOD mice. Diabetes. 2014; 63(8):2821-32. [PubMed: 24696449]

Haskins K, Portas M, Bradley B, Wegmann D, Lafferty KJ. T-lymphocyte clone specific for pancreatic islet antigen. Diabetes. 1988; 37:1444-1448. [PubMed: 2458291]

Herold KC, Hagopian W, Auger JA, Poumian-Ruiz E, Taylor L, Donaldson D, Gitelman SE, Harlan DM, Xu D, Zivin RA, Bluestone JA. Anti-CD3 monoclonal antibody in new-onset type 1 diabetes mellitus. N Engl J Med. 2002; 346(22):1692-1698. [PubMed: 12037148]

Hoffenberg EJ, Emery LM, Barriga KJ, Bao F, Taylor J, Eisenbarth GS, Haas JE, Sokol RJ, Taki I, Norris JM, Rewers M. Clinical features of children with screening-identified evidence of celiac disease. Pediatrics. 2004; 113(5):1254-1259. [PubMed: 15121938]

Howson JM, Cooper JD, Smyth DJ, Walker NM, Stevens H, She JX, Eisenbarth GS, Rewers M, Todd JA, Akolkar B, Concannon P, Erlich HA, Julier C, Morahan G, Nerup J, Nierras C, Pociot F, Rich SS. Evidence of gene-gene interaction and age-at-diagnosis effects in type 1 diabetes. Diabetes. 2012; 61(11):3012-3017. [PubMed: 22891215]

Huang HS, Peng JT, She JY, Zhang LP, Chao CC, Liu KH, She J-X. HLA-encoded susceptibility to insulin-dependent diabetes mellitus is determined by DR and DQ genes as well as their linkage disequilibrium in a Chinese population. Hum Immunol. 1995; 44:210-219. [PubMed: 8770634]

Hulbert C, Riseili B, Rojas M, Thomas JW. B cell specificity contributes to the outcome of diabetes in nonobese diabetic mice. J Immunol. 2001; 167(10):5535-5538. [PubMed: 11698422]

Husebye ES, Anderson MS. Autoimmune polyendocrine syndromes: clues to type 1 diabetes pathogenesis. Immunity. 2010; 32(4):479-487. [PubMed: 20412758]

Hyoty H. Enterovirus infections and type 1 diabetes. Ann Med. 2002; 34(3):138-147. [PubMed: 12173683]

Jaberi-Douraki M, Schnell S, Pietropaolo M, Khadra A. Unraveling the contribution of pancreatic beta-cell suicide in autoimmune type 1 diabetes. J Theor Biol. 2014; 14 pii: S0022-5193(14)00270-7.

Jaeger C, Hatziagelaki E, Petzoldt R, Bretzel RG. Comparative analysis of organ-specific autoantibodies and celiac disease--associated antibodies in type 1 diabetic patients, their firstdegree relatives, and healthy control subjects. Diabetes Care. 2001; 24(1):27-32. [PubMed: 11194235]

Julier C, Hyer RN, Davies J, Merlin F, Soularue P, Briant L, Cathelineau G, Deschamps I, Rotter JI, Froguel P, Boitard C, Bell JI, Lathrop GM. Insulin-IGF2 region encodes a gene implicated in HLA-DR4-dependent diabetes susceptibility. Nature. 1991; 354:155-159. [PubMed: 1944595]

Kaprio J, Tuomilehto J, Koskenvuo M, Romanov K, Reunanen A, Eriksson J, Stengard J, Kesaniemi YA. Concordance for type 1 (insulin-dependent) and type 2 (non-insulin-dependent) diabetes mellitus in a population-based cohort of twins in Finland. Diabetologia. 1992; 35:1060-1067. [PubMed: 1473616] 
Karlsen AE, Hagopian WA, Grubin CE, Dube S, Disteche CM, Adler DA, Barmeier H, Mathewes S, Grant FJ, Foster D, Lernmark Å. Cloning and primary structure of a human isoform of glutamic acid decarboxylase from chromosome 10. Proc Natl Acad Sci USA. 1991; 88:8337-8341. [PubMed: 1924293]

Kastbom A, Strandberg G, Lindroos A, Skogh T. Anti-CCP antibody test predicts the disease course during 3 years in early rheumatoid arthritis (the Swedish TIRA project). Ann Rheum Dis. 2004; 63(9):1085-1089. [PubMed: 15308517]

Katahira M, Segawa S, Maeda H, Yasuda Y. Effect of human leukocyte antigen class II genes on acute-onset and slow-onset type 1 diabetes in the Japanese population. Hum Immunol. 2010; 71(8):789-94. [PubMed: 20510319]

Kavvoura FK, Ioannidis JP. CTLA-4 gene polymorphisms and susceptibility to type 1 diabetes mellitus: a HuGE Review and meta-analysis. Am J Epidemiol. 2005; 162(1):3-16. [PubMed: 15961581]

Kawasaki E, Yu L, Gianani R, Verge CF, Babu S, Bonifacio E, Eisenbarth GS. Evaluation of islet cella antigen (ICA) 512/IA-2 autoantibody radioassay using overlapping ICA512/IA-2 constructs. J Clin Endocrinol Metab. 1997; 82:375-380. [PubMed: 9024221]

Kennedy GC, German MS, Rutter WJ. The minisatellite in the diabetes susceptibility locus IDDM2 regulates insulin transcription. Nat Genet. 1995; 9:293-298. [PubMed: 7773292]

Khalil I, D'Auriol L, Gobet M, et al. A combination of HLA-DQ beta Asp 57-negative and HLA-DQ Arg 52 confers susceptibility to insulin-dependent diabetes mellitus. J Clin Invest. 1990; 85:13151319. [PubMed: 2318983]

Kimpimaki T, Kupila A, Hamalainen AM, Kukko M, Kulmala P, Savola K, Simell T, Keskinen P, Ilonen J, Simell O, Knip M. The first signs of beta-cell autoimmunity appear in infancy in genetically susceptible children from the general population: the Finnish Type 1 Diabetes Prediction and Prevention Study. J Clin Endocrinol Metab. 2001; 86(10):4782-4788. [PubMed: 11600541]

Kleffel S, Vergani A, Tezza S, Ben Nasr M, Niewczas MA, Wong S, Bassi R, D'Addio F, Schatton T, Abdi R, Atkinson M, Sayegh MH, Wen L, Wasserfall CH, O’Connor KC, Fiorina P. Interleukin-10+ Regulatory B Cells Arise Within Antigen-Experienced CD40+ B Cells to Maintain Tolerance to Islet Autoantigens. Diabetes. 2014 Sep 3. pii: DB_131639.

LaPorte RE, Matsushima M, Chang Y-F. Prevalence and incidence of insulin-dependent diabetes. Diabetes in America. 1995:37-46.

Lee PT, Putnam A, Benlaga K, Teyton L, Gottlieb PA, Bendelac A. Testing the NKT cell hypothesis of human IDDM pathogenesis. J Clin Invest. 2002; 110:793-800. [PubMed: 12235110]

Liu E, Lee HS, Aronsson CA, Hagopian WA, Koletzko S, Rewers MJ, Eisenbarth GS, Bingley PJ, Bonifacio E, Simell V, Agardh D. Risk of pediatric celiac disease according to HLA haplotype and country. N Engl J Med. 2014; 371(1):42-49. [PubMed: 24988556]

Lonnrot M, Korpela K, Knip M, Ilonen J, Simell O, Korhonen S, Savola K, Muona P, Simell T, Koskela P, Hyoty H. Enterovirus infection as a risk factor for beta-cell autoimmunity in a prospectively observed birth cohort: the Finnish Diabetes Prediction and Prevention Study. Diabetes. 2000; 49(8):1314-1318. [PubMed: 10923631]

Lucassen AM, Screaton GR, Julier C, Elliot TJ, Lathrop M, Bell JI. Regulation of insulin gene expression by the IDDM associated, insulin locus haplotype. Hum Mol Genet. 1994; 4(4):501506. [PubMed: 7633396]

Lund T, O'Reilly L, Hutchings P, Kanagawa O, Simpson E, Gravely R, Chandler P, Dyson J, Picard JK, Edwards A, Kioussis D, Cook A. Prevention of insulin-dependent diabetes mellitus in nonobese diabetic mice by transgenes encoding modified I-A beta chain or normal I-E alpha chain. Nature. 1990; 345:727-729. [PubMed: 2163026]

Mahon JL, Sosenko JM, Rafkin-Mervis L, Krause-Steinrauf H, Lachin JM, Thompson C, Bingley PJ, Bonifacio E, Palmer JP, Eisenbarth GS, Wolfsdorf J, Skyler JS. The TrialNet Natural History Study of the Development of Type 1 Diabetes: objectives, design, and initial results. Pediatr Diabetes. 2009; 10(2):97-104. [PubMed: 18823409] 
Mallone R, Martinuzzi E, Blancou P, Novelli G, Afonso G, Dolz M, Bruno G, Chaillous L, Chatenoud L, Bach JM, van Endert P. CD8+ T-cell responses identify beta-cell autoimmunity in human type 1 diabetes. Diabetes. 2007; 56(3):613-621. [PubMed: 17327428]

Marron MP, et al. Insulin-dependent diabetes mellitus (IDDM) is associated with CTLA4 polymorphisms in multiple ethnic groups. Hum Mol Genet. 1997; 6(8):1275-1282. [PubMed: 9259273]

Masson-Bessiere C, Sebbag M, Girbal-Neuhauser E, Nogueira L, Vincent C, Senshu T, Serre G. The major synovial targets of the rheumatoid arthritis-specific antifilaggrin autoantibodies are deiminated forms of the alpha- and beta-chains of fibrin. J Immunol. 2001; 166(6):4177-4184. [PubMed: 11238669]

Mathews CE, Pietropaolo SL, Pietropaolo M. Reduced thymic expression of islet antigen contributes to loss of self-tolerance. Ann N Y Acad Sci. 2003; 1005:412-417. [PubMed: 14679103]

Mbunwe E, Van der Auwera BJ, Vermeulen I, Demeester S, Van DA, Balti EV, Van AS, Derdelinckx L, Dorchy H, De SJ, van Schravendijk C, Wenzlau JM, Hutton JC, Pipeleers D, Weets I, Gorus FK. HLA-A*24 is an independent predictor of 5-year progression to diabetes in autoantibodypositive first-degree relatives of type 1 diabetic patients. Diabetes. 2013; 62(4):1345-1350. [PubMed: 23160529]

Michels AW. Targeting the trimolecular complex. Clin Immunol. 2013; 149(3):339-344. [PubMed: 23537861]

Michels AW, Ostrov DA, Zhang L, Nakayama M, Fuse M, McDaniel K, Roep BO, Gottlieb PA, Atkinson MA, Eisenbarth GS. Structure-based selection of small molecules to alter allele-specific MHC class II antigen presentation. J Immunol. 2011; 187(11):5921-5930. [PubMed: 22043012]

Miyazaki T, Uno M, Uehira M, Kikutani H, Kishimoto T, Kmoto M, Nishimoto H, Miyazaki JI. Direct evidence for the contribution of unique I-A ${ }^{\mathrm{NOD}}$ to the development of insulitis in non-obese diabetic mice. Nature. 1990; 345:722-724. [PubMed: 2113614]

Morales P, Martinez-Laso J, Martin-Villa JM, Corell A, Vicario JL, Varela P, Perez-Aciego P, ArnaizVillena A. High frequency of the HLA-DRB1*0405(Dw15)-DQw8 haplotype in Spaniards and its relationship to diabetes susceptibility. Hum Immunol. 1991; 32:170-175. [PubMed: 1774197]

Morel PA, Dorman JS, Todd JA, McDevitt HO, Trucco M. Aspartic acid at position 57 of the HLADQ beta chain protects against Type I diabetes: a family study. Proc Natl Acad Sci USA. 1988; 85:8111-8115. [PubMed: 3186714]

Morran MP, Casu A, Arena VC, Pietropaolo S, Zhang YJ, Satin LS, Nelson P, Omenn GS, Trucco M, Becker DJ, Pietropaolo M. Humoral autoimmunity against the extracellular domain of the neuroendocrine autoantigen IA-2 heightens the risk of type 1 diabetes. Endocrinology. 2010; 151(6):2528-2537. [PubMed: 20382696]

Moscarello MA, Mastronardi FG, Wood DD. The role of citrullinated proteins suggests a novel mechanism in the pathogenesis of multiple sclerosis. Neurochem Res. 2007; 32(2):251-256. [PubMed: 17031564]

Mziaut H, Trajkovski M, Kersting S, Ehninger A, Altkruger A, Lemaitre RP, Schmidt D, Saeger HD, Lee MS, Drechsel DN, Muller S, Solimena M. Synergy of glucose and growth hormone signalling in islet cells through ICA512 and STAT5. Nat Cell Biol. 2006; 8(5):435-445. [PubMed: 16622421]

Naji A, Silvers SK, Bellgrau D, Barker CF. Spontaneous diabetes in rats: destruction of islets is prevented by immunological tolerance. Science. 1981; 213:1390-1392. [PubMed: 6791286]

Nakayama M, Abiru N, Moriyama H, Babaya N, Liu E, Miao D, Yu L, Wegmann DR, Hutton JC, Elliott JF, Eisenbarth GS. Prime role for an insulin epitope in the development of type 1 diabetes in NOD mice. Nature. 2005; 435(7039):220-223. [PubMed: 15889095]

Naumov YN, Bahjat KS, Gausling R, Abraham R, Exley MA, Koezuka Y, Balk SB, Strominger JL, Clare-Salzler M, Wilson SB. Activation of CD1d-restricted T cells protects NOD mice from developing diabetes by regulating dendritic cell subsets. Proc Natl Acad Sci USA. 2001; 98:13838-13843. [PubMed: 11707602]

Nepom GT, Kwok WT. Molecular basis for HLA-DQ association in IDDM. Diabetes. 1998; 47:11771184. [PubMed: 9703314] 
Nielsen DS, Krych L, Buschard K, Hansen CH, Hansen AK. Beyond genetics. Influence of dietary factors and gut microbiota on type 1 diabetes. FEBS Lett. 2014; 588:4234-4243. [PubMed: 24746688]

Nishimoto H, Kikutani H, Yamamura K, Kishimoto T. Prevention of autoimmune insulitis by expression of I-E molecules in NOD mice. Nature. 1987; 328:432-434. [PubMed: 3302721]

Noorchashm H, Noorchashm N, Kern J, Rostami SY, Barker CF, Naji A. B-cells are required for the initiation of insulitis and sialitis in nonobese diabetic mice. Diabetes. 1997; 46(6):941-946. [PubMed: 9166663]

Orban T, Bundy B, Becker DJ, DiMeglio LA, Gitelman SE, Goland R, Gottlieb PA, Greenbaum CJ, Marks JB, Monzavi R, Moran A, Peakman M, Raskin P, Russell WE, Schatz D, Wherrett DK, Wilson DM, Krischer JP, Skyler JS. Costimulation modulation with abatacept in patients with recent-onset type 1 diabetes: follow-up 1 year after cessation of treatment. Diabetes Care. 2014; 37(4):1069-1075. [PubMed: 24296850]

Orchard TJ, Forman JS, LaPorte RE, Ferrell RE, Drash AL. Host and environmental interactions in diabetes mellitus. J Chronic Dis. 1986; 39:979-999. [PubMed: 3539976]

Owerbach D, Nerup J. Restriction fragment length polymorphism of the insulin gene in diabetes mellitus. Diabetes. 1982; 31:275-277. [PubMed: 6295855]

Palmer JP, Asplin CM, Clemons P, Lyen K, Tatpati O, Raghu PK, Paquette TL. Insulin antibodies in insulin-dependent diabetics before insulin treatment. Science. 1983; 222:1337-1339. [PubMed: 6362005]

Peakman M, Stevens EJ, Lohmann T, Narendran P, Dromey J, Alexander A, Tomlinson AJ, Trucco M, Gorga JC, Chicz RM. Naturally processed and presented epitopes of the islet cell autoantigen IA-2 eluted from HLA-DR4. J Clin Invest. 2000; 104(10):1449-1457. [PubMed: 10562307]

Pietropaolo M, Becker DJ, LaPorte RE, Dorman JS, Riboni S, Rudert WA, Mazumdar S, Trucco M. Progression to insulin-requiring diabetes in seronegative prediabetic subjects: the role of two HLA-DQ high risk haplotypes. Diabetologia. 2002; 45:66-76. [PubMed: 11845225]

Pietropaolo M, Castano L, Babu S, Buelow R, Kuo Y-LS, Martin S, Martin A, Powers AC, Prochazka M, Naggert J, Leiter EH, Eisenbarth GS. Islet cell autoantigen 69 kDa (ICA69): Molecular cloning and characterization of a novel diabetes associated autoantigen. J Clin Invest. 1993; 92:359-371. [PubMed: 8326004]

Pietropaolo M, Eisenbarth GS. Autoantibodies in human diabetes. Curr Dir Autoimmun. 2001; 4:252282. [PubMed: 11569406]

Pietropaolo M, Towns R, Eisenbarth GS. Humoral autoimmunity in type 1 diabetes: prediction, significance, and detection of distinct disease subtypes. Cold Spring Harb Perspect Med. 2012; 2(10)

Pietropaolo, M.; Trucco, M. Major histocompatibility locus and other genes that determine the risk of development of Type 1 diabetes mellitus. In: LeRoith, D.; Taylor, SI.; Olefsky, JM., editors. Diabetes Mellitus. A fundamental and clinical text. Lippincott Williams \& Wilkins; Philadelphia: 2000. p. 399-410.

Pugliese A, Gianani R, Moromisato R, Awdeh ZL, Alper CA, Erlich HA, Jackson RA, Eisenbarth GS. HLA-DQB1*0602 is associated with dominant protection from diabetes even among islet cell antibody positive first degree relatives of patients with insulin-dependent diabetes. Diabetes. 1995; 44:608-613. [PubMed: 7789622]

Pugliese A, Kawasaki E, Zeller M, Yu L, Babu S, Solimena M, Moraes CT, Pietropaolo M, Friday RP, Trucco M, Ricordi C, Allen M, Noble JA, Erlich HA, Eisenbarth GS. Sequence analysis of the diabetes-protective human leukocyte antigen-DQB $1 * 0602$ allele in unaffected, islet cell antibody-positive first degree relatives and in rare patients with Type 1 diabetes. J Clin Endocrinol Metab. 1999; 84:1722-1728. [PubMed: 10323407]

Pugliese A, Yang M, Kusmarteva I, Heiple T, Vendrame F, Wasserfall C, Rowe P, Moraski JM, Ball S, Jebson L, Schatz DA, Gianani R, Burke GW, Nierras C, Staeva T, Kaddis JS, CampbellThompson M, Atkinson MA. The Juvenile Diabetes Research Foundation Network for Pancreatic Organ Donors with Diabetes (nPOD) Program: goals, operational model and emerging findings. Pediatr Diabetes. 2014; 15(1):1-9. [PubMed: 24325575] 
Pugliese A, Zeller M, Fernandez A Jr, Zalcberg LJ, Barlett RJ, Ricordi C, Pietropaolo M, Eisenbarth GS, Bennett ST, Patel DD. The insulin gene is transcribed in the human thymus and transcription levels correlate with allelic variation at the INS VNTR-IDDM2 susceptibility locus for type 1 diabetes. Nat Genet. 1997; 15:293-297. [PubMed: 9054945]

Redondo MJ, Eisenbarth GS. Genetic control of autoimmunity in Type I diabetes and associated disorders. Diabetologia. 2002; 45:605-622. [PubMed: 12107741]

Redondo MJ, Rewers M, Yu L, Garg S, Pilcher CC, Elliott RB, Eisenbarth GS. Genetic determination of islet cell autoimmunity in monozygotic twin, dizygotic twin, and non-twin siblings of patients with type 1 diabetes: prospective twin study. BMJ. 1999; 318(7185):698-702. [PubMed: 10074012]

Reyes A, Wu M, McNulty NP, Rohwer FL, Gordon JI. Gnotobiotic mouse model of phage bacterial host dynamics in the human gut. Proc Nat Acad Sci USA. 2013; 110:20236-20241. [PubMed: 24259713]

Richardson SJ, Horwitz MS. Is type 1 diabetes “going viral”? Diabetes. 2014; 63(7):2203-2205. [PubMed: 24962917]

Richardson SJ, Leete P, Bone AJ, Foulis AK, Morgan NG. Expression of the enteroviral capsid protein VP1 in the islet cells of patients with type 1 diabetes is associated with induction of protein kinase R and downregulation of Mcl-1. Diabetologia. 2013; 56(1):185-193. [PubMed: 23064357]

Roep BO, Tree TI. Immune modulation in humans: implications for type 1 diabetes mellitus. Nat Rev Endocrinol. 2014; 10(4):229-242. [PubMed: 24468651]

Rotwein P, Chyn R, Chirgwin J, Cordell B, Goodman HM, Permutt MA. Polymorphism in the 5'flanking region of the human insulin gene and its possible relation to Type II diabetes. Science. 1981; 213:1117-1120. [PubMed: 6267694]

Rowe RE, Leech NJ, Nepom GT, McCulloch DK. High genetic risk for IDDM in the Pacific Northwest: first report from the Washington State diabetes prediction study. Diabetes. 1994; 43:87-94. [PubMed: 8262322]

Schwartz, BD. The major histocompatibility complex and disease susceptibility. In: Bennett, JC.; Plum, F., editors. Cecil Textbook of Medicine. W.B. Saunders Company; Philadelphia: 1996. p. 1424-1432.

Serreze DV, Chapman HD, Varnum DS, Hanson MS, Reifsnyder PC, Richard SD, Fleming SA, Leiter EH, Shultz LD. B lymphocytes are essential for the initiation of T cell-mediated autoimmune diabetes: analysis of a new "speed congenic" stock of NOD. Ig mu null mice. J Exp Med. 1996; 184(5):2049-2053. [PubMed: 8920894]

Serreze DV, Fleming SA, Chapman HD, Richard SD, Leiter EH, Tisch RM. B lymphocytes are critical antigen-presenting cells for the initiation of T cell-mediated autoimmune diabetes in nonobese diabetic mice. J Immunol. 1998; 161(8):3912-3918. [PubMed: 9780157]

Sharif S, Arreaza GA, Zucker P, Mi QS, Delovitch TL. Regulation of autoimmune disease by natural killer T cells. J Mol Med. 2002; 80:290-300. [PubMed: 12021841]

She JX. Susceptibility to type I diabetes: HLA-DQ and DR revisited. Immunol Today. 1996; 17:323329. [PubMed: 8763818]

Shi FD, Flodstrom M, Balasa B, Kim SH, Van Gunst K, Strominger JL, Wilson SB, Sarvetnick N. Germ line deletion of the CD1 locus exacerbates diabetes in the NOD mouse. Proc Natl Acad Sci USA. 2001; 98(12):6777-6782. [PubMed: 11390999]

Silveira PA, Johnson E, Chapman HD, Bui T, Tisch RM, Serreze DV. The preferential ability of B lymphocytes to act as diabetogenic APC in NOD mice depends on expression of self-antigenspecific immunoglobulin receptors. Eur J Immunol. 2002; 32(12):3657-3666. [PubMed: 12516557]

Skyler JS, Cefalu WT, Koudries IA, Landschulz WH, Balagtas CC, Cheng SL, Gelfand RA. Efficacy of inhaled human insulin in type 1 diabetes mellitus: a randomised proof-of-concept study. Lancet. 2001; 357:331-335. [PubMed: 11210993]

Slattery RM, Kjer-Nielsen L, Allison J, Charlton B, Mandel TE, Miller JFAP. Prevention of diabetes in non-obese diabetic I-Ak transgenic mice. Nature. 1990; 345:724-726. [PubMed: 1972779] 
Smyth DJ, Plagnol V, Walker NM, Cooper JD, Downes K, Yang JH, Howson JM, Stevens H, McManus R, Wijmenga C, Heap GA, Dubois PC, Clayton DG, Hunt KA, van Heel DA, Todd JA. Shared and distinct genetic variants in type 1 diabetes and celiac disease. N Engl J Med. 2008a; 359(26):2767-2777. [PubMed: 19073967]

Smyth DJ, Plagnol V, Walker NM, Cooper JD, Downes K, Yang JH, Howson JM, Stevens H, McManus R, Wijmenga C, Heap GA, Dubois PC, Clayton DG, Hunt KA, van Heel DA, Todd JA. Shared and distinct genetic variants in type 1 diabetes and celiac disease. N Engl J Med. 2008b; 359(26):2767-2777. [PubMed: 19073967]

Soderlin MK, Kastbom A, Kautiainen H, Leirisalo-Repo M, Strandberg G, Skogh T. Antibodies against cyclic citrullinated peptide (CCP) and levels of cartilage oligomeric matrix protein (COMP) in very early arthritis: relation to diagnosis and disease activity. Scand J Rheumatol. 2004; 33(3):185-188. [PubMed: 15228190]

Solimena M, Folli F, Denis-Donini S, Comi GC, Pozza G, De Camilli P, Vicari AM. Autoantibodies to glutamic acid decarboxylase in a patient with stiffman syndrome, epilepsy, and Type I diabetes mellitus. N Engl J Med. 1988; 318:1012-1020. [PubMed: 3281011]

Stadinski BD, Delong T, Reisdorph N, Reisdorph R, Powell RL, Armstrong M, Piganelli JD, Barbour G, Bradley B, Crawford F, Marrack P, Mahata SK, Kappler JW, Haskins K. Chromogranin A is an autoantigen in type 1 diabetes. Nat Immunol. 2010; 11(3):225-231. [PubMed: 20139986]

Steck AK, Johnson K, Barriga KJ, Miao D, Yu L, Hutton JC, Eisenbarth GS, Rewers MJ. Age of islet autoantibody appearance and mean levels of insulin, but not GAD or IA-2 autoantibodies, predict age of diagnosis of type 1 diabetes: diabetes autoimmunity study in the young. Diabetes Care. 2011; 34(6):1397-1399. [PubMed: 21562325]

Szopa TM, Titchener PA, Portwood ND, Taylor KW. Diabetes mellitus due to viruses - some recent developments. Diabetologia. 1993; 36:687-695. [PubMed: 8405735]

Tang Q, Bluestone JA. Regulatory T-cell therapy in transplantation: moving to the clinic. Cold Spring Harb Perspect Med. 2013; 3(11)

Tisch R, McDevitt H. Insulin-dependent diabetes mellitus. Cell. 1996; 85:291-297. [PubMed: 8616883]

Todd JA, Bell JI, McDevitt HO. HLA-DQb gene contributes to susceptibility and resistance to insulindependent diabetes mellitus. Nature. 1987; 329:599-604. [PubMed: 3309680]

Todd JA, et al. Robust associations of four new chromosome regions from genome-wide analyses of type 1 diabetes. Nat Genet. 2007; 39(7):857-864. [PubMed: 17554260]

van Lummel M, Duinkerken G, van Veelen PA, de Ru A, Cordfunke R, Zaldumbide A, GomezTourino I, Arif S, Peakman M, Drijfhout JW, Roep BO. Posttranslational modification of HLADQ binding islet autoantigens in type 1 diabetes. Diabetes. 2014; 63(1):237-247. [PubMed: 24089515]

Vang T, Congia M, Macis MD, Musumeci L, Orru V, Zavattari P, Nika K, Tautz L, Tasken K, Cucca F, Mustelin T, Bottini N. Autoimmune-associated lymphoid tyrosine phosphatase is a gain-offunction variant. Nat Genet. 2005; 37(12):1317-1319. [PubMed: 16273109]

Vehik K, Hamman RF, Lezotte D, Norris JM, Klingensmith G, Bloch C, Rewers M, Dabelea D. Increasing incidence of type 1 diabetes in 0- to 17-year-old Colorado youth. Diabetes Care. 2007; 30(3):503-509. [PubMed: 17327312]

Verge CF, Gianani R, Kawasaki E, Yu L, Pietropaolo M, Jackson RA, Chase PH, Eisenbarth GS. Prediction of type I diabetes mellitus in first degree relatives using a combination of insulin, glutamic acid decarboxylase and ICA512bdc/IA-2 autoantibodies. Diabetes. 1996; 45:926-933. [PubMed: 8666144]

Verge CF, Gianani R, Yu L, Pietropaolo M, Smith T, Jackson RA, Soeldner JS, Eisenbarth GS. Late progression to diabetes and evidence for chronic beta-cell autoimmunity in identical twins of patients with type I diabetes. Diabetes. 1995; 44(10):1176-9. [PubMed: 7556954]

Vong AM, Daneshjou N, Norori PY, Sheng H, Braciak TA, Sercarz EE, Gabaglia CR. Spectratyping analysis of the islet-reactive T cell repertoire in diabetic NOD Igmu(null) mice after polyclonal B cell reconstitution. J Transl Med. 2011; 9:101. [PubMed: 21722394] 
Wagener DK, Sacks JM, LaPorte RE, MacGregor JM. The Pittsburgh study of insulin-dependent diabetes mellitus: risk for diabetes among relatives of IDDM. Diabetes. 1982; 31:136-144. [PubMed: 6759229]

Warram JH, Krolewski AS, Gottlieb MS, Kahn CR. Differences in risk of insulin-dependent diabetes in offspring of diabetic mothers and diabetic fathers. N Engl J Med. 1984; 311:149-152. [PubMed: 6738600]

Warram, JH.; Rich, SS.; Krolewski, AS. Epidemiology and genetics of diabetes mellitus. In: Kahn, CR.; Weir, GC., editors. Joslin's diabetes mellitus. Lea and Febiger; Philadelphia: 1994. p. 201

Wasmeier C, Hutton JC. Molecular cloning of phogrin, a protein tyrosyne phosphatase homologue localized to insulin secretory granule membranes. J Biol Chem. 1996; 271(30):18161-18170. [PubMed: 8663434]

Wen L, Ley RE, Volchkov PY, Stranges PB, Avanesyan L, Stonebraker AC, Hu C, Wong FS, Szot GL, Bluestone JA, Gordon JI, Chervonsky AV. Innate immunity and intestinal microbiota in the development of Type 1 diabetes. Nature. 2008; 455(7216):1109-13. [PubMed: 18806780]

Wenzlau JM, Juhl K, Yu L, Moua O, Sarkar SA, Gottlieb P, Rewers M, Eisenbarth GS, Jensen J, Davidson HW, Hutton JC. The cation efflux transporter ZnT8 (Slc30A8) is a major autoantigen in human type 1 diabetes. Proc Natl Acad Sci USA. 2007; 104(43):17040-17045. [PubMed: 17942684]

Wenzlau JM, Moua O, Liu Y, Eisenbarth GS, Hutton JC, Davidson HW. Identification of a major humoral epitope in Slc30A8 (ZnT8). Ann N Y Acad Sci. 2008; 1150:252-255. [PubMed: 19120306]

Wijesekara N, Chimienti F, Wheeler MB. Zinc, a regulator of islet function and glucose homeostasis. Diabetes Obes Metab. 2009; 11(Suppl 4):202-14. 202-214. [PubMed: 19817803]

Wijesekara N, Dai FF, Hardy AB, Giglou PR, Bhattacharjee A, Koshkin V, Chimienti F, Gaisano HY, Rutter GA, Wheeler MB. Beta cell-specific Znt8 deletion in mice causes marked defects in insulin processing, crystallisation and secretion. Diabetologia. 2010; 53(8):1656-1668. [PubMed: 20424817]

Wilson SB, Kent SC, Horton HF, Hill AA, Bollyky PL, Hafler DA, Strominger JL, Byrne MC. Multiple differences in gene expression in regulatory Va24JaQ T cells from identical twins discordant for type I diabetes. Proc Natl Acad Sci USA. 2000; 97:7411-7416. [PubMed: 10840051]

Wilson SB, Kent SC, Patton KT, Orban T, Jackson RA, Exley M, Porcelli S, Schatz DA, Atkinson MA, Balk SP, Strominger JL, Hafler DA. Extreme Th1 bias of invariant Va24JaQ T cells in type 1 diabetes. Nature. 1998; 391:177-181. [PubMed: 9428763]

Winer S, Tsui H, Lau A, Song A, Li X, Cheung RK, Sampson A, Afifiyan F, Elford A, Jackowski G, Becker DJ, Santamaria P, Ohashi P, Dosch HM. Autoimmune islet destruction in spontaneous type 1 diabetes is not beta-cell exclusive. Nat Med. 2003; 9:198-205. [PubMed: 12539039]

Wong FS, Wen L, Tang M, Ramanathan M, Visintin I, Daugherty J, Hannum LG, Janeway CA Jr, Shlomchik MJ. Investigation of the role of B-cells in type 1 diabetes in the NOD mouse. Diabetes. 2004; 53(10):2581-2587. [PubMed: 15448087]

Wucherpfennig KW, Eisenbarth GS. Type 1 diabetes. Nat Immunol. 2001; 2(9):767-768. [PubMed: 11526380]

Xu P, Wu Y, Zhu Y, Dagne G, Johnson G, Cuthbertson D, Krischer JP, Sosenko JM, Skyler JS. Prognostic performance of metabolic indexes in predicting onset of type 1 diabetes. Diabetes Care. 2010; 33(12):2508-2513. [PubMed: 20807869]

Yu L, Liu Y, Miao D, Wenzlau J, Davidson H, Hutton J, Eisenbarth GS. Triple chimeric islet autoantigen IA2-ZnT8WR to facilitate islet autoantibody determination. J Immunol Meth. 2010; 353(1-2):20-23.

Zhang L, Crawford F, Yu L, Michels A, Nakayama M, Davidson HW, Kappler JW, Eisenbarth GS. Monoclonal antibody blocking the recognition of an insulin peptide-MHC complex modulates type 1 diabetes. Proc Natl Acad Sci USA. 2014; 111(7):2656-2661. [PubMed: 24550292]

Zhang XM, Wang HY, Luo YY, Ji LN. HLA-DQ, DR allele polymorphism of type 1 diabetes in the Chinese population: a meta-analysis. Chin Med J. 2009; 122(8):980-6. [PubMed: 19493426] 
Zipris D, Lien E, Nair A, Xie JX, Greiner DL, Mordes JP, Rossini AA. TLR9-signaling pathways are involved in Kilham rat virus-induced autoimmune diabetes in the biobreeding diabetes-resistant rat. J Immunol. 2007; 178(2):693-701. [PubMed: 17202329] 


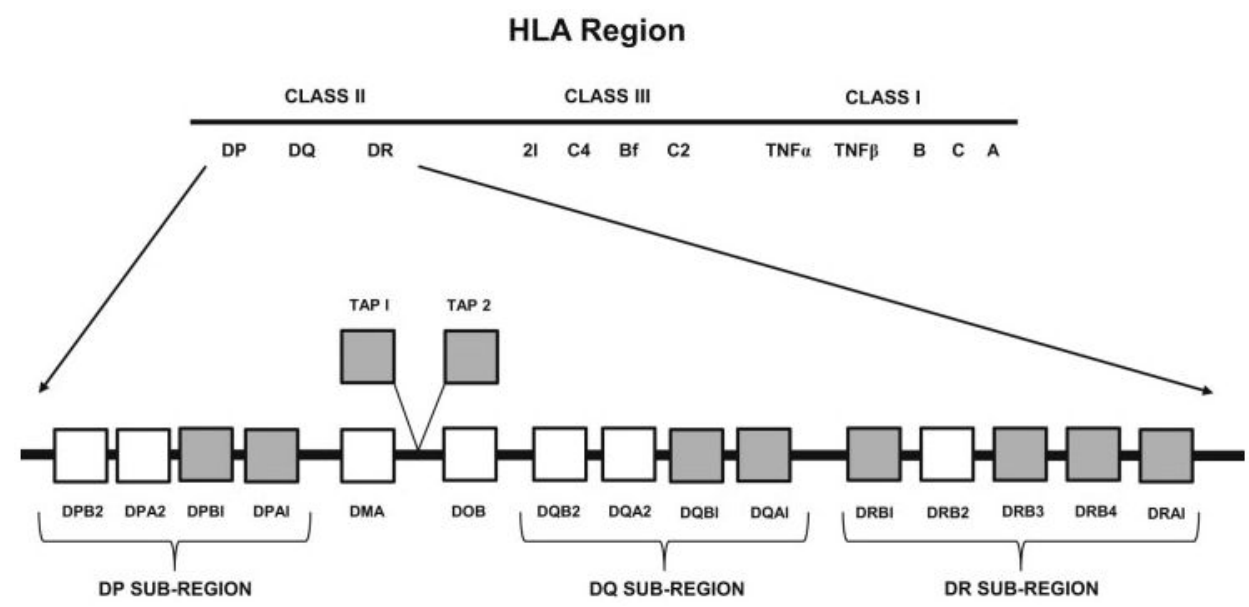

Figure 1.

Schematic representation of the human leukocyte antigen (HLA) complex on chromosome 6 . The genes that encode a protein product are indicated in grey color; the genes encoding nonfunctional products, or products that have not been characterized, are indicated in white color. 


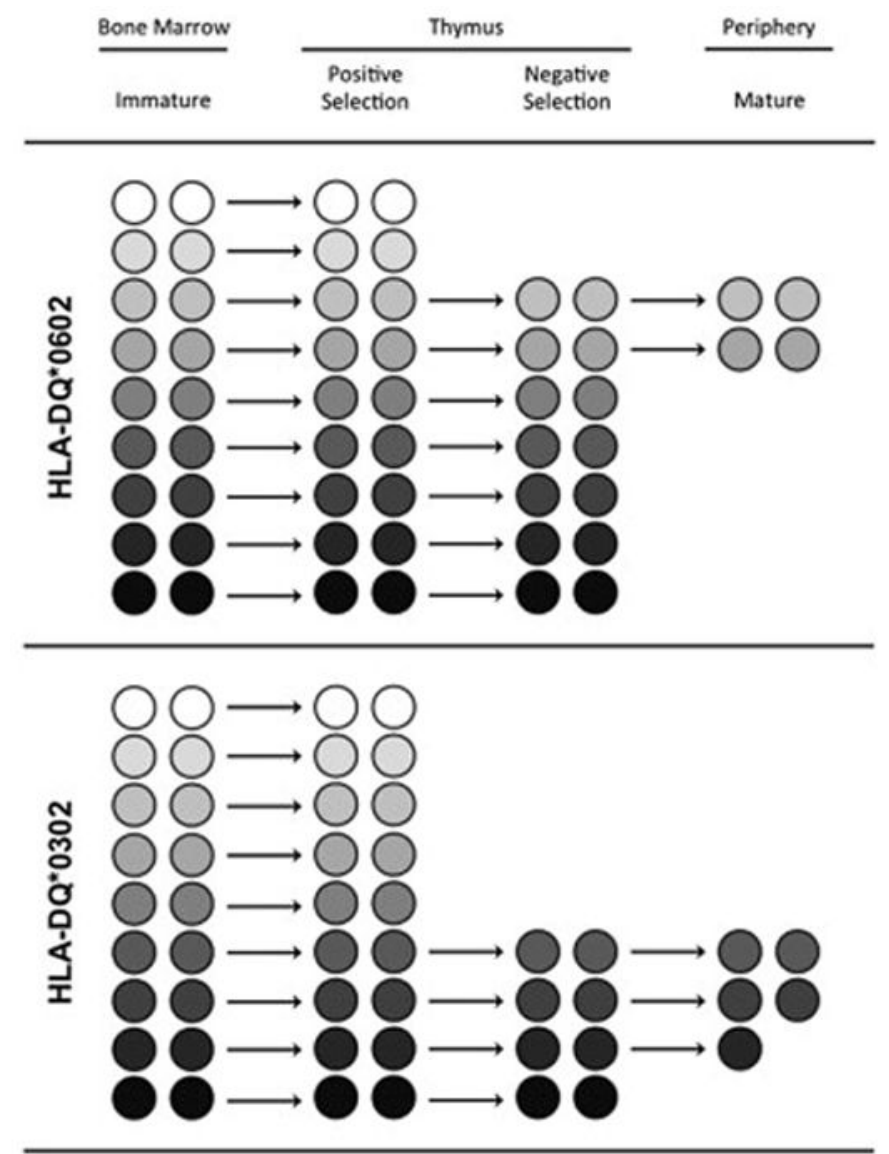

Figure 2.

Both positive and negative thymic selections contribute to form the repertoire of mature $\mathrm{T}$ cells in the periphery from immature $\mathrm{T}$ cells originated in the bone marrow. Subjects carrying HLA-DQ alleles associated with resistance to disease, such as HLA-DQ*0602, will be able to negatively select in the thymus $\mathrm{T}$ cells with high affinity to self-peptides (O), so that no autoreactive T cells would be present in peripheral blood and the likelihood of developing diabetes would be reduced. In contrast, subjects who carry susceptibility alleles with low affinity for self-peptides $(\bigcirc)$, such as HLA-DQ*0302, will negatively select less efficiently autoreactive $\mathrm{T}$ cells, which will egress from the thymus and be present (even in small numbers) among peripheral T cells (Modified from Nepon GT and Kwok WT.

Diabetes 1998. 47:177). 

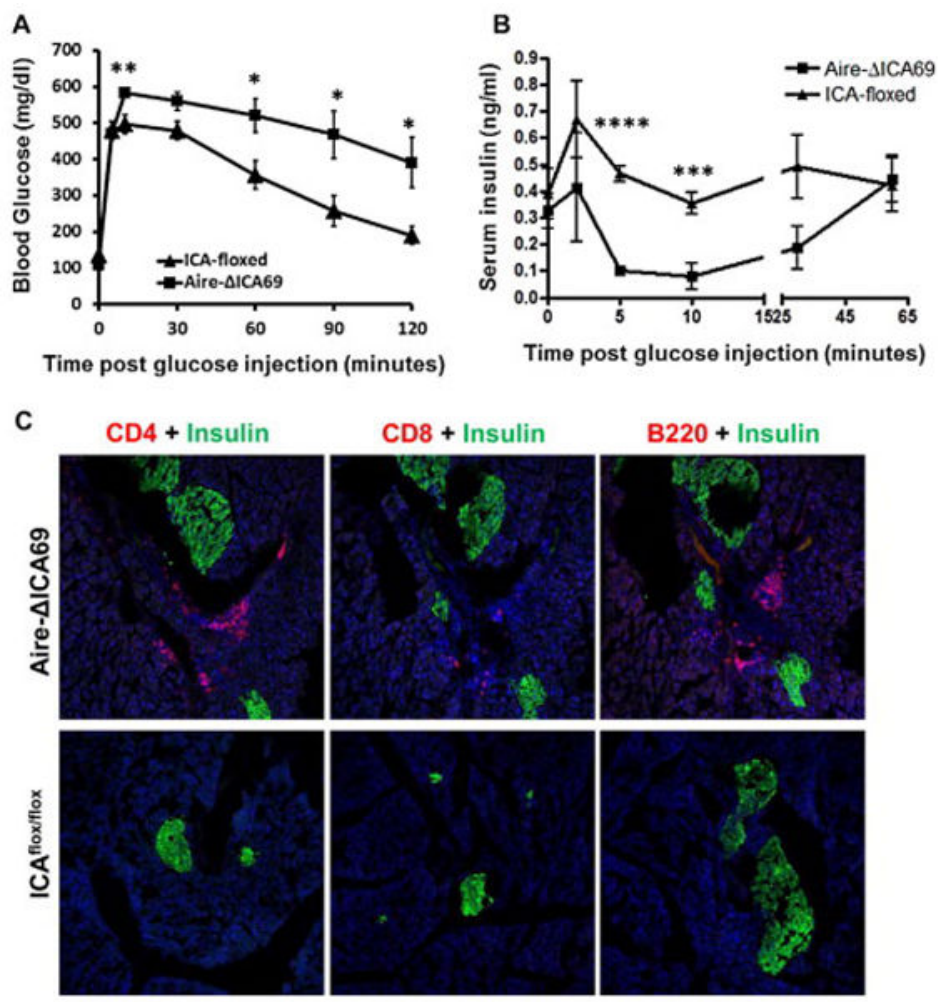

Figure 3.

Aire- $\Delta \mathrm{ICA} 69$ mice spontaneously develop anti-islet autoimmune responses. A. Intraperitoneal glucose tolerance test. 12-week old Aire- $\Delta$ ICA69 mice $(n=7)$ were challenged with a bolus of $2 \mathrm{~g} / \mathrm{kg}$ D-glucose, in comparison to ICA69flox/flox mice $(\mathrm{n}=6)$. Data are presented as mean \pm SEM. Unpaired Student $t$ test, $* \mathrm{p}<0.05 ; * * \mathrm{p}<0.01$. B. Serum insulin levels in the Aire- $\Delta \mathrm{ICA} 69(\mathrm{n}=7)$ and the ICA69flox/flox $(\mathrm{n}=6)$ mice. Sera were harvested after overnight fasting and challenged after i.p. injection of $2 \mathrm{~g} / \mathrm{kg}$ of D-glucose. Data are presented as mean \pm SEM. Unpaired Student $\mathrm{t}$ test, $* * * \mathrm{p}<0.005 ; * * * * \mathrm{p}<0.001$. C. Immunohistochemistry showing lymphocyte infiltration of pancreatic islets in 16-week old Aire- $\Delta$ ICA69 mice. Cryosections of pancreata harvested from either the Aire- $\Delta$ ICA69 (upper panel), or the Ica1flox/flox (lower panel) mice, were stained with anti-CD4 (red), anti-CD8 and anti-B220 antibodies and counter-stained with anti-insulin (green) antibodies (With permission from the Journal of Autoimmunity). 


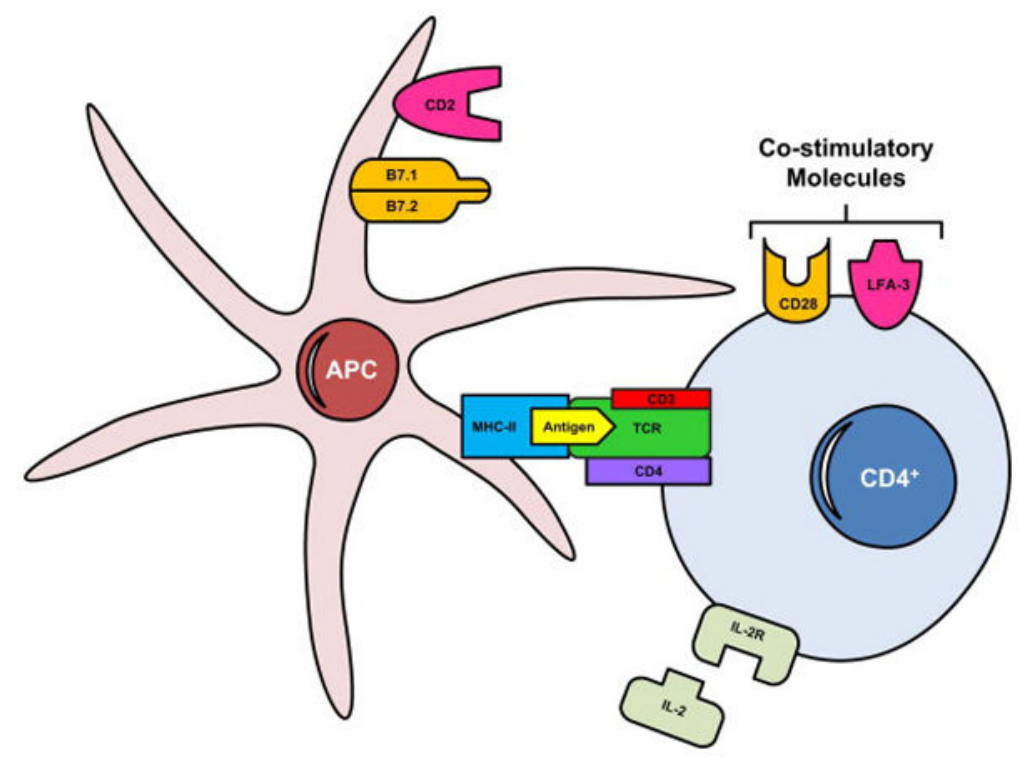

Figure 4. Autoantigen Epitope Spreading in T1DM

As the severity of symptoms associated with T1DM increases over time, so does the number of autoantigens recognized by the immune system. Epitope spreading begins once the immune system is triggered within the pancreas, leading to the processing and presentation of self-antigens. As $\beta$-cell destruction takes place, multiple self-antigens become targets of the immune system. During this process, insulin is thought to be the first antigenic target, followed by other $\beta$-cell associated components, such as glutamic-acid decarboxylase 65 (GAD65) and islet-cell antigen-2 (IA-2) and ZnT8. Over time autoantigens are processed differently, creating various recognition epitopes for a given antigen. The tree symbolizes an immune system at birth which lacks autoimmunity. As the tree grows towards autoimmune T1DM, its limbs represent targeted self-antigens which develop. As T1DM progresses, multiple limbs grow off the tree, each from a different antigen. These growing limbs next branch off, representing the unique epitopes recognized from differential processing of similar self-peptides. As T1DM develops, the tree grows towards autoimmunity by increasing both the number of limbs and the number of branches on a given limb, representing the process of epitope spreading observed in disease progression. 


\section{Epitope Spreading in T1D}

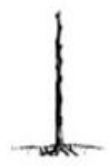

Birth

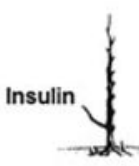

$<5$ years

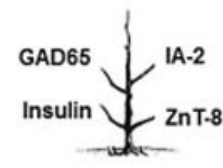

Autoimmune Disease Progression

Figure 5.

Schematic representation of initiation of the immunologic response to an autoantigen. The antigen binds to a groove in MHC class II molecules on antigen-presenting cells (APCs). This binding allows the antigen to be presented to antigen receptors on autoreactive CD4 inducer or helper T cells which, in T1DM, initiate immune-mediated injury to the pancreatic beta cells. Furthermore, the respective binding of B7 proteins and lymphocyte functional antigen-3 (LFA-3) on APCs to CD28 and CD2 on T cells are important costimulatory pathways that further enhance $\mathrm{T}$ cell activation. Other molecules can also participate in the immune response, such as the binding of interleukin-2 to its receptor (IL-2R). 


\section{Table 1}

Empiric risk of Type 1 diabetes

\begin{tabular}{|c|c|}
\hline Population & Type 1 Diabetes Risk \% \\
\hline \multicolumn{2}{|l|}{ Low Risk } \\
\hline No FDR affected, positive for HLA protective genes & 0.01 \\
\hline No FDR affected & 0.4 \\
\hline FDR Affected, postive for HLA protective genes & 0.3 \\
\hline \multicolumn{2}{|l|}{ Intermediate Risk } \\
\hline No affected FDR, positive for HLA risk genes & 4 \\
\hline One Affected FDR & 5 \\
\hline Father with T1DM & 3 \\
\hline Mother with T1DM & 5 \\
\hline Sibling with T1DM & 8 \\
\hline \multicolumn{2}{|l|}{ High Risk } \\
\hline One affected FDR, positive for HLA high risk genes & 10-20 \\
\hline Multiple FDRs affected & $20-25$ \\
\hline \multicolumn{2}{|l|}{ Very High Risk } \\
\hline Multiple FDRs affected, positive for HLA risk genes & 50 \\
\hline Sibling affected, positive for HLA risk genes & 30-70 \\
\hline Identical twin affected & $30-70$ \\
\hline
\end{tabular}




\section{Table 2}

HLA Class II DR-DQ genotypes and T1DM Susceptibility in Caucasians

\begin{tabular}{|l|l|l|l|l|}
\hline HLA-DR & DQA1 & DQB1 & DRB1 & Susceptibility \\
\hline$D R 2$ & 0102 & 0602 & 1501 & Protective \\
\hline$D R 2$ & 0102 & 0502 & 1601 & Predisposing \\
\hline$D R 2$ & 0103 & 0601 & 1502 & Neutral \\
\hline$D R 3$ & 0501 & 0201 & 0301 & High Risk \\
\hline$D R 4$ & 0301 & 0302 & 0401 & High Risk \\
\hline$D R 4$ & 0301 & 0302 & 0402 & Predisposing \\
\hline$D R 4$ & 0301 & 0302 & 0403 & Lower Risk \\
\hline$D R 4$ & 0301 & 0302 & 0404 & Predisposing \\
\hline$D R 4$ & 0301 & 0302 & 0405 & High Risk \\
\hline$D R 4$ & 0301 & 0301 & 0401 & Neutral \\
\hline$D R 4$ & 0301 & 0303 & 0401 & Neutral \\
\hline$D R 7$ & 0201 & 0303 & 0701 & Protective \\
\hline$D R 6$ & 0101 & 0503 & 1401 & Protective \\
\hline
\end{tabular}

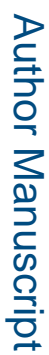

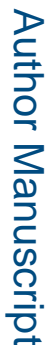

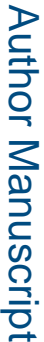

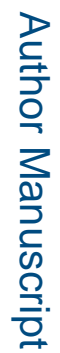


Table 3

Most characterized islet autoantigens associated with Type 1 diabetes.

\begin{tabular}{|c|c|c|c|}
\hline & Localization & Humoral Response & Cellular Response \\
\hline Insulin ${ }^{*}$ & $\begin{array}{l}\text { Secretory granules pancreatic } \beta \\
\text { cells. Human thymus and PAE } \\
\text { cells (Peripheral Antigen } \\
\text { Expressing Cells) }\end{array}$ & $\begin{array}{l}\text { Insulin autoantibodies are found in } \\
\text { virtually } 100 \% \text { of young children }(<5 \text { years } \\
\text { of age) before the onset of Type } 1 \text { diabetes. } \\
\text { Correlation with younger age and fast rate } \\
\text { of progression to insulin requirement in } \\
\text { first-degree relatives of IDDM patients. } \\
\text { Prophylactic subcutaneous injection of } \\
\text { insulin, oral and intranasal administration } \\
\text { prevents Type } 1 \text { diabetes in NOD mice. }\end{array}$ & $\begin{array}{l}\text { PBLs from humans and } \\
\text { NOD mice react with } \\
\text { insulin } \beta \text {-chain. }\end{array}$ \\
\hline GAD65 ${ }^{*}$ and GAD67 & $\begin{array}{l}\text { Synaptic-like microvesicles of } \\
\text { neuroendocrine cells. Present in } \\
\text { testis and ovary. Human thymus } \\
\text { and PAE cells }\end{array}$ & $\begin{array}{l}\text { A subset of 64-kDa autoantibodies } \\
\text { recognize GAD. Autoantibodies to GAD65 } \\
\text { are present in 70-80\% of prediabetic } \\
\text { subjects or newly diagnosed diabetic } \\
\text { patients. GAD antibodies are also detected } \\
\text { in patients with stiff man syndrome, and } \\
\text { with autoimmune thyroid disease. } \\
\text { Radioimmunoassay of in vitro transcribed/ } \\
\text { translated GAD65 useful for large-scale } \\
\text { screening. }\end{array}$ & $\begin{array}{l}\text { PBL responses to GAD65 } \\
\text { in newly diagnosed } \\
\text { diabetic patients and in } \\
\text { NOD mice }\end{array}$ \\
\hline $\begin{array}{l}\operatorname{ICA512}(\mathrm{IA}-2)^{*} \text { and phogrin } \\
(\mathrm{IA}-2 \beta)\end{array}$ & $\begin{array}{l}\text { Neurosecretory granules } \\
\text { (pancreatic } \beta \text { cells, CNS, } \\
\text { pituitary, adrenal). Human } \\
\text { thymus and PAE cells }\end{array}$ & $\begin{array}{l}\text { Autoantibodies to ICA512(IA-2) are } \\
\text { present in } ~ 60 \% \text { of prediabetics or newly } \\
\text { diagnosed IDDM patients. Relationship } \\
\text { between } 37,000 \text { and } 40,000 \text { Da tryptic } \\
\text { fragments and ICA512(IA-2). } \\
\text { Radioimmunoassay of in vitro transcribed/ } \\
\text { translated ICA512(IA-2) useful for large- } \\
\text { scale screening. }\end{array}$ & $\begin{array}{l}\text { PBL responses in newly } \\
\text { diagnosed diabetic } \\
\text { patients. }\end{array}$ \\
\hline ZnT8 (Slc30A8) ${ }^{*}$ & $\begin{array}{l}\mathrm{Zn} \text { transporter, a member of the } \\
\text { cation diffusion facilitator } \\
\text { family exhibiting abundant } \\
\text { expression in } \beta \text { cells. Expressed } \\
\text { also extra- pancreatically }\end{array}$ & $\begin{array}{l}\text { Targeted by autoantibodies in } 60-80 \% \text { of } \\
\text { newly diagnosed T1DM patients and in ca. } \\
26 \% \text { of patients negative for other islet } \\
\text { autoantibodies. Relevant polymorphic } \\
\text { variants are Trp325 and Arg325 }\end{array}$ & $\begin{array}{l}\text { Autoreactive T cells to } \\
\text { ZnT8 found in human } \\
\text { T1DM }\end{array}$ \\
\hline $\begin{array}{l}\text { Islet Cell Autoantigen } 69 \text { kDa } \\
\text { (ICA69) }\end{array}$ & $\begin{array}{l}\text { Predominantly Neuroendocrine } \\
\text { tissues. Human and mouse } \\
\text { thymus }\end{array}$ & $\begin{array}{l}\text { Autoantibodies to ICA } 69 \text { can be detected } \\
\text { in } 43 \% \text { of prediabetic subjects by Western } \\
\text { blotting. }\end{array}$ & $\begin{array}{l}\text { Association between } \\
\text { HLA-DR3 and PBL } \\
\text { responses in newly } \\
\text { diagnosed Type } 1 \\
\text { diabetics. }\end{array}$ \\
\hline Chromogranin A & $\begin{array}{l}\text { Neurosecretory granules. } \\
\text { Neuroendocrine tissues }\end{array}$ & Circulating ChgA found in NOD mice. & $\begin{array}{l}\text { Autoreactive T cells to } \\
\text { ChgA found in NOD mice }\end{array}$ \\
\hline Carboxypeptidase $\mathbf{H}$ & Neurosecretory granules & $\begin{array}{l}\text { Autoantibodies to carboxypeptidase } \mathrm{H} \\
\text { found in } \sim 20 \% \text { of prediabetics. }\end{array}$ & Present \\
\hline Ganglioside GM2- 1 & Pancreatic islet cells & $\begin{array}{l}\text { Autoantibodies to GM2-1 detected in }-80 \% \\
\text { of prediabetic subjects and NOD mice. }\end{array}$ & $?$ \\
\hline Imogen 38 (38 kDa) & $\begin{array}{l}\text { Mitochondria; widely } \\
\text { distributed with variable levels } \\
\text { of expression }\end{array}$ & $\begin{array}{l}\text { Presence of circulating antibodies to } 38 \text { - } \\
\mathrm{kDa} \text { proteins. Possible presence of } \\
\text { antibodies to imogen } 38 \text {. }\end{array}$ & $\begin{array}{l}\text { PBLs from newly } \\
\text { diagnosed diabetics } \\
\text { proliferate to imogen } 38\end{array}$ \\
\hline Glima 38 & $\begin{array}{l}\text { Amphiphilic N-Asp glycated } \beta \\
\text { cell membrane protein that is } \\
\text { expressed in islets and neuronal } \\
\text { cell lines. }\end{array}$ & $\begin{array}{l}\text { Autoantibodies to Glima } 38 \text { can be } \\
\text { detected in 14-22.7\% of newly diagnosed } \\
\text { diabetics and prediabetics. The majority of } \\
\text { these patients are negative for GAD } 65 \\
\text { and/or ICA512(IA-2) autoantibodies. }\end{array}$ & $?$ \\
\hline Peripherin & Neuronal cells & $\begin{array}{l}\text { Autoantibody response against peripherin } \\
\text { in NOD mice and in patients Type } 1 \\
\text { diabetes and other autoimmune disorders. }\end{array}$ & $\begin{array}{l}\mathrm{T} \text { cell responses against } \\
\text { peripherin in NOD mice. }\end{array}$ \\
\hline Heat-shock protein (Hsp60) & Ubiquitously inducible & $\begin{array}{l}\text { Antibodies to Hsp60 in prediabetic NOD } \\
\text { mice. }\end{array}$ & $\begin{array}{l}\text { Hsp60-reactive T-cells can } \\
\text { accelerate disease in } \\
\text { prediabetic NOD mice. }\end{array}$ \\
\hline
\end{tabular}

* Biochemical autoantibody assays readily available for large screening programs.

Mol Aspects Med. Author manuscript; available in PMC 2016 April 01. 